\begin{tabular}{|l|l|l|}
\hline MAR 272000 & Paga 1 of \\
Sta $4 \$ 5$ & ENGINEERING DATA TRANSMITTAL & 1. EDt 628669 \\
\hline
\end{tabular}




SNF-5809

Revision 0

\section{Shippingport Spent Fuel Canister System Description}

EDT -628669

Total Pages: 46

Prepared for the U.S. Department of Energy

Assistant Secretary for Environmental Management

Project Hanford Management Contractor for the

U.S. Department of Energy under Contract DE-AC06-96RL13200

Fluor Hanford

P.O. Box 1000

Richland, Washington

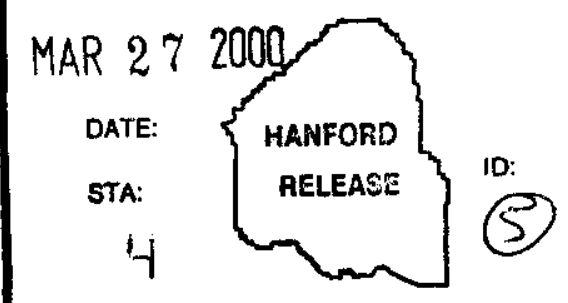




\section{INFORMATION CLEARANCE FORM}

\begin{tabular}{ll|l}
\hline \multicolumn{1}{|c|}{ A. Information Category } & B. Document Number SNF-5809 \\
\cline { 3 - 3 }$\square$ Abstract & $\square$ Journal Article & C. Title \\
$\square$ Summary & $\square$ Internet & Shippingport Spent Fuel Canister System Description \\
$\square$ Visual Aid & $\square$ Software & \\
$\square$ Full Paper & $\bigotimes$ Report & \\
$\square$ Other & & D. Internet Address \\
\cline { 3 - 3 } & &
\end{tabular}

E. Required Information

1. Is document potentially classified? $O$ no $O$ Yes (MANDATORY)

4. Does Information Contain the Following: (MANDATORY)

a. New or Novel (Patentable) Subject Matter? ONo OYes If "Yes", Disclosure No:

If Yes Manager's Signature Required

2. Internal Review Required? 1 ? If Yes, Document Signatures Below

Counsel

Program

3. References in the Information are Applied Technology ONo OYes Export Controlled information Ono Ores

b. Information Received in Confidence, Such as Proprietary and/or Inventions?

No OYes If "Yes", Affix Appropriate Legends/Notices.
c. Copyrights?
No
OYes
If "Yes", Attach Permission.
d. Trademarks?
No
OYes
If "Yes", Identify in Document.

5. Is Information requiring submission to OSTI? $\bigcirc$ No $\bigcirc$ Yes If Yes $U C-513$ and $B \& R-$ EWO 4 J 1110

6. Release Level? $\bigcirc$ Public $\bigcirc$ Limited

7. Charge Code $2 W 200$

F. Complete for a Journal Article

1. Titje of Journal

G. Complete for a Presentation

1. Title for Conference or Meeting

2. Group Sponsoring

3. Date of Conference

5. Will Information be Published in Proceedings? $O$ No $O$ Yes

4. City/State

H. Author/Requestor

D.M. Johnson $D / 1+1 / 1$ (Print and Sign)

6. Will Material be Handed Out? $\bigcirc$ No $\bigcirc$ Yes Responsible Manager RL $M C \mathrm{CH}_{2}$ R.L.MCCormack $3 / 24 / 00$

I. Reviewers Yes Print Signature Print and Sign)
General Counsel
Office of External Affairs
$\square$
-
DOE-RL
Other
Other
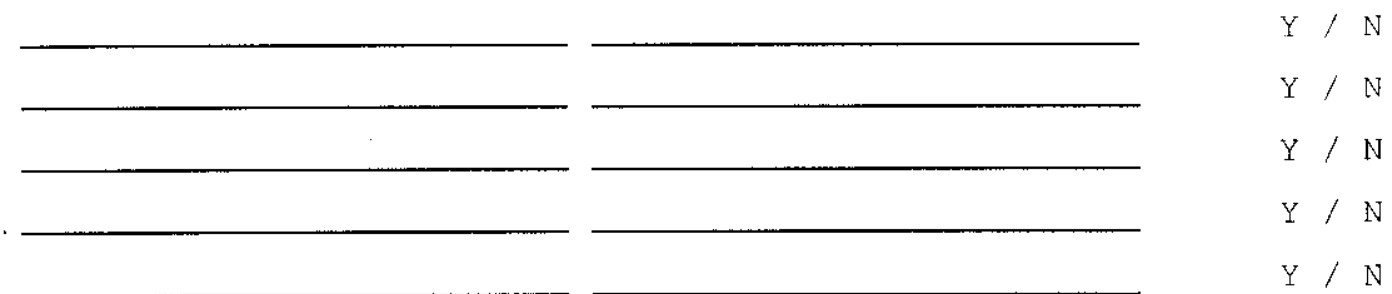

Public $\mathrm{Y} / \mathrm{N}$ (If $\mathrm{N}$, complete $\mathrm{J}$ )

J. If Information Includes Sensitive Information and is not to be released to the Public indicate category below.

$\square$ Personal/Private $\square$ Export Controlled

$\square$ Proprietary

$\square$ Business-Sensitive

$\square$ Procurement-Sensitive

$\square$ Predecisional

$\square$ Patentable

$\square$ UCNI

$\square$ Other (Specify)

K. If Additional Comments, Please Attach Separate Sheet 


\section{RELEASE AUTHORIZATION}

Document Number: SNF-5089 REV 0

Document Title: $\quad$ Shippingport Spent Fuel Canister System Description

This document, reviewed in accordance with DOE Order 241.1, "Scientific and Technical Information Management," and 241.1-1, "Guide to the Management of Scientific and Technical Information," does not contain classified or sensitive unclassified information and is:

\section{APPROVED FOR PUBLIC RELEASE}
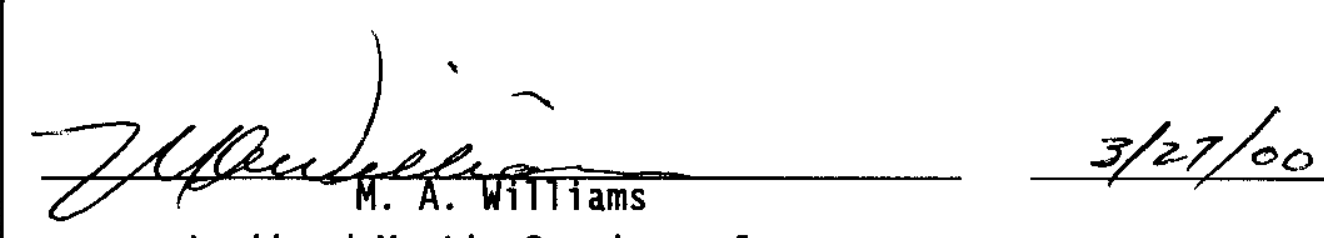

Lockheed Mart in Services, Inc. Document Control/Information Clearance

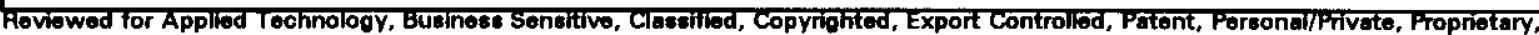
Protected CRADA, Trademark, Unclassified Controlled Nuclear Information.

LEGAL DISCLAIMER. This report was prepered as an account of work sponsored by an agency of the United States Government. Neither the United States Government nor any agency thereof, not any of their employees, nor any of their contractors, subcontractors or their employees, makes any warranty, express or implied, or assumes any logal liability or respontibility for the accuracy, completeness, or any third party's use or the results of such use of any information, apparatus, product, or process disclosed, or represents that its use would not infringe privately owned rohts. Aoference herein to any epecific commercial product, process, or service by trade name, trademark, manufacturer, or otherwise, does not necesearily constitute or imply its ondorsement, recommendation, or favoring by the United States Government or any agency thereof or its contractors or subcontractors. The views and opinions of authors expresesd heroin do not necesearily state or reflect those of the United States Government or any agency thereof. This report has been reproduced from the best available copy. Printed in the United States of America. 
SNF-5809

Revision 0

\title{
Shippingport Spent Fuel Canister System Description
}

\author{
O.L. Kruger
}

Fluor Hanford

Date Published

March 2000

Prepared for the U.S. Department of Energy

Assistant Secretary for Environmental Management

\section{Fluor Hanford}

P.O. Box 1000

Richland, Washington 


\section{LEGAL DISCLAIMER}

This report was prepared as an account of work sponsored by an agency of the United States Government. Neither the United States Government nor any agency thereof, nor any of their employees, nor any of their contractors, subcontractors or their employees, makes any warranty, express or implied, or assumes any legal liability or responsibility for the accuracy, completeness, or any third party's use or the results of such use of any information, apparatus, product, or process disclosed, or represents that its use would not infringe privately owned rights. Reference herein to any specific commercial product, process, or service by trade name, trademark, manufacturer, or otherwise, does not necessarily constitute or imply its endorsement, recommendation, or favoring by the United States Government or any agency thereof or its contractors or subcontractors. The views and opinions of authors expressed herein do not necessarily state or reflect those of the United States Government or any agency thereof.

This report has been reproduced from the best available copy. Available in paper copy and microfiche.

Available electronically at

http://www.doe.gov/bridge. Available for a processing fee to the U.S. Department of Energy and its contractors, in paper, from:

U.S. Department of Energy

Office of Scientific and Technical Information

P.O. Box 62

Oak Ridge, TN 37831-0062

phone: 865-576-8401

fax: 865-576-5728

email: reports@adonis.osti.gov(423)576-8401 
SNF-5809, REV 0

This page intentionally left blank. 


\section{CONTENTS}

1.0 INTRODUCTION

2.0 SHIPPINGPORT SPENT FUEL CANISTER SYSTEM SUMMARY DESCRIPTION... .1

2.1 Shippingport Spent Fuel Canister Boundaries.............................................................. 1

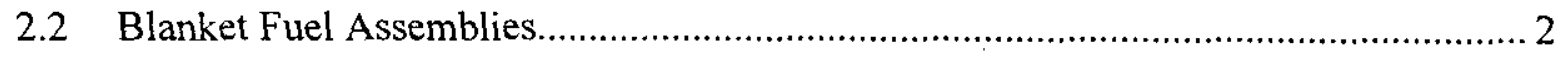

2.3 Shippingport Spent Fuel Canister Interfaces .......................................................... 3

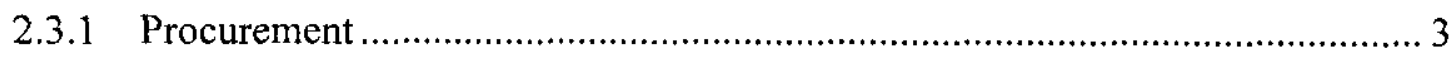

2.3.2 Storage and Transfer to Site Facilities ........................................................... 3

2.3.3 Cask Transport Trailer ............................................................................ 3

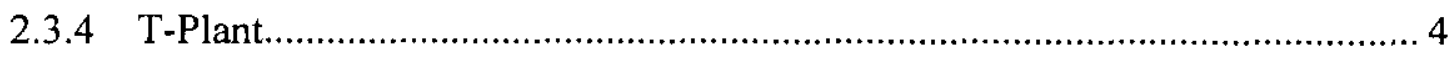

2.3.5 Canister Storage Building ...................................................................... 4

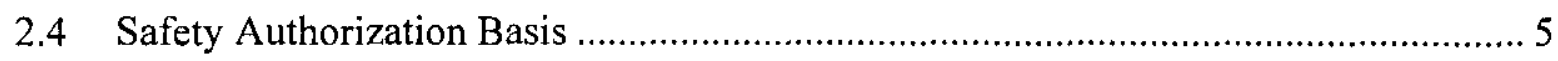

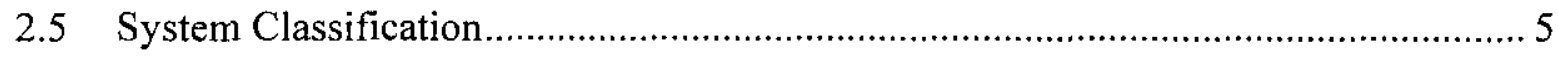

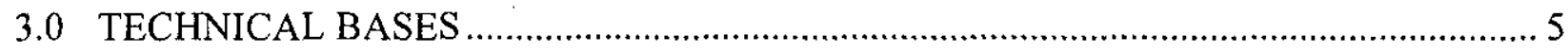

3.1 Functional and Performance Requirements .......................................................

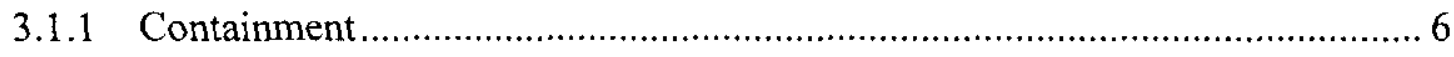

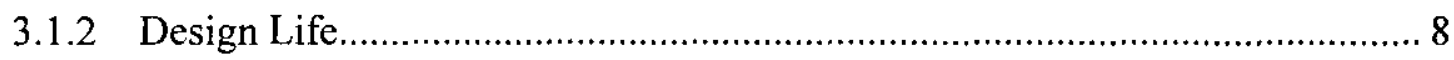

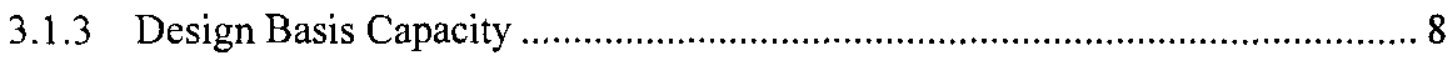

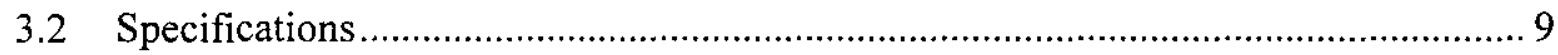

4.0 SYSTEM AND PROCESS EQUIPMENT DESIGN DESCRIPTION ................................ 9

4.1 Shippingport Spent Fuel Canister System …………................................................. 9

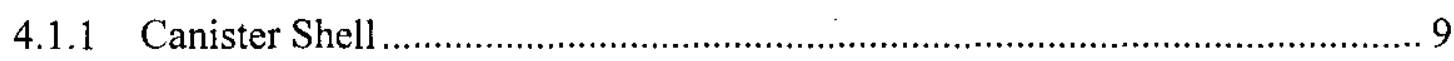

4.1.2 Shield Plug and Locking and Lifting Ring ……......................................... 10

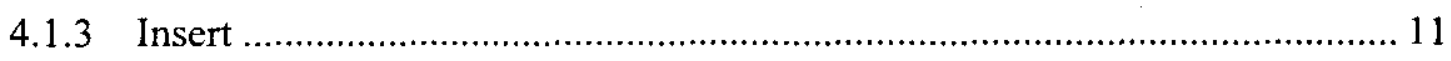

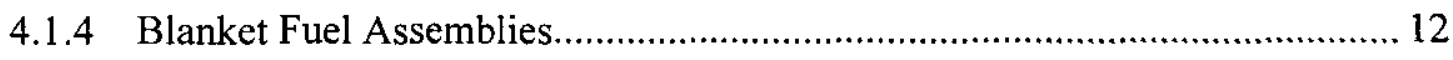

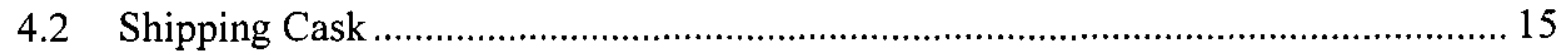

4.3 Cask-Shippingport Spent Fuel Canister Transport Trailer ...................................... 16 


\section{CONTENTS cont.}

4.4 Drying and Inerting System …….................................................................... 17

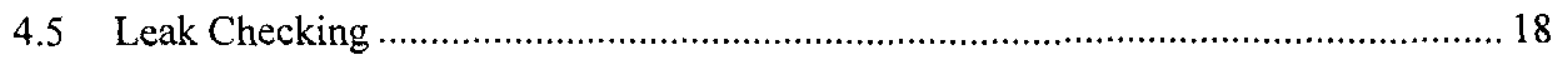

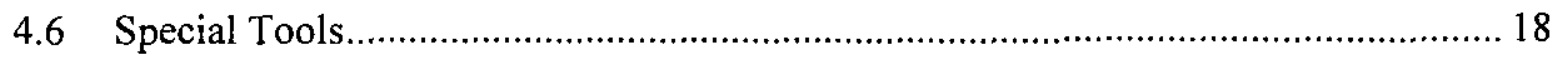

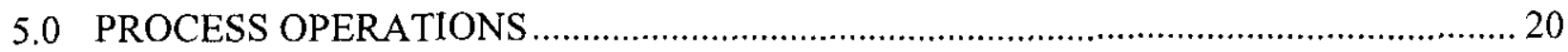

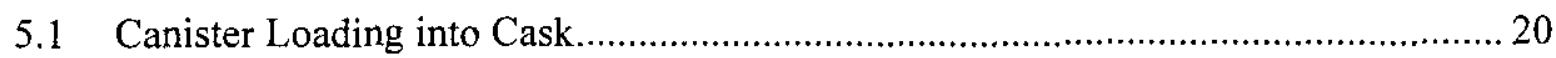

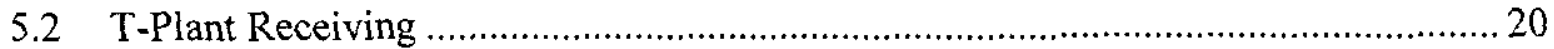

5.3 Shippingport Spent Fuel Canister Preparation........................................................ 21

5.4 Blanket Fuel Assembly Loading ......................................................................... 21

5.5 Shippingport Spent Fuel Canister Processing ……………………….................. 22

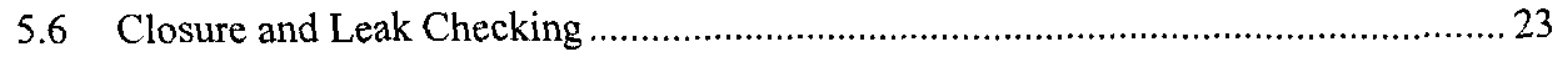

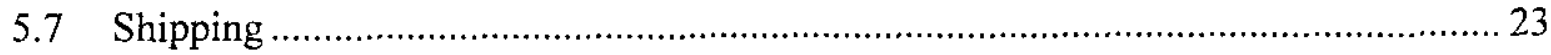

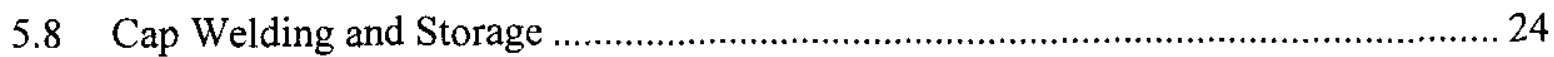

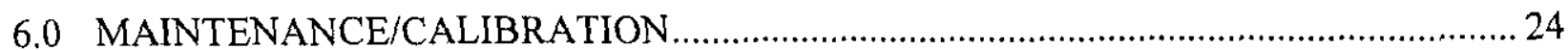

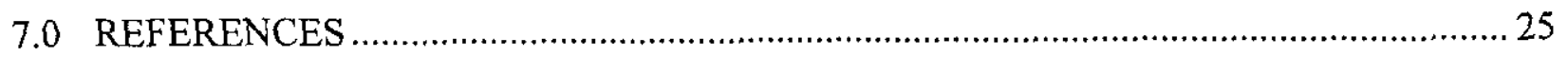


SNF-5809, REV 0

\section{LIST OF FIGURES}

Figure 1. Shippingport Spent Fuel Canister Assembly ..........................................................

Figure 2. Shippingport Pressurized Water Reactor Core 2 Blanket Fuel Assembly ..................F-2

Figure 3. Shield Plug with Cross-Section Showing Port Plug Valve, Cover Plate, and Canister Seal.

Figure 4. Shippingport Pressurized Water Reactor Core 2 Blanket Fuel Assembly Details......F-4

Figure 5. Shippingport Pressurized Water Reactor Core 2 Blanket Fuel Cluster Details. .........F-5

Figure 6. Schematic Diagram of Drying and Inerting System Module.....................................F-6

Figure 7. Shippingport Spent Fuel Process Operations Flow Diagram.....................................F-7

Figure 8. Shippingport Spent Fuel Operational Sequence Flow Diagram..................................F-8

\section{LIST OF TABLES}

Table 1. Actinide Masses in Shippingport Core 2 Blanket Fuel Assemblies as a Function of

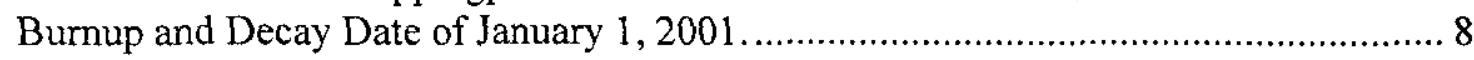

Table 2. Physical Characteristics of the Shippingport Pressurized Water Reactor Core 2 Blanket Fuel Assemblies.

Table 3. Estimated Burnup and Number of Shippingport Blanket Fuel Assemblies in Each Burnup Category Based on Available Plutonium Buildup Records. 


\section{LIST OF TERMS}

$\begin{array}{ll}\text { ALARA } & \text { as low as reasonably achievable } \\ \text { ASME } & \text { American Society of Mechanical Engineers } \\ \text { BFA } & \text { blanket fuel assembly } \\ \text { CSB } & \text { Canister Storage Building } \\ \text { FSAR } & \text { final safety analysis report } \\ \text { ISB } & \text { Interim Safety Basis } \\ \text { LWR } & \text { light water reactor } \\ \text { MCO } & \text { multi-canister overpack } \\ \text { MHM } & \text { multi-canister overpack handling machine } \\ \text { MSLD } & \text { mass spectrometer leak detector } \\ \text { NRC } & \text { U.S. Nuclear Regulatory Commission } \\ \text { PWR } & \text { pressurized water reactor } \\ \text { SNF } & \text { spent nuclear fuel } \\ \text { SSC } & \text { structure, system, and component } \\ \text { SSFC } & \text { Shippingport Spent Fuel Canister }\end{array}$


SNF-5809, REV 0

\section{SHIPPINGPORT SPENT FUEL CANISTER SYSTEM DESCRIPTION}

\subsection{INTRODUCTION}

In 1978 and 1979, a total of 72 blanket fuel assemblies (BFAs), irradiated during the operating cycles of the Shippingport Atomic Power Station's Pressurized Water Reactor (PWR) Core 2 from April 1965 to February 1974, were transferred to the Hanford Site and stored in underwater storage racks in Cell $2 \mathrm{R}$ at the 221-T Canyon (T-Plant). The initial objective was to recover the produced plutonium in the BFAs, but this never occurred and the fuel assemblies have remained within the water storage pool to the present time.

The Shippingport Spent Fuel Canister (SSFC) is a confinement system that provides safe transport functions (in conjunction with the TN-WHC cask) and storage for the BFAs at the Canister Storage Building (CSB). The current plan is for these BFAs to be retrieved from wet storage and loaded into SSFCs for dry storage. The sealed SSFCs containing BFAs will be vacuum dried, internally backfilled with helium, and leak tested to provide suitable confinement for the BFAs during transport and storage. Following completion of the drying and inerting process, the SSFCs are to be delivered to the CSB for closure welding and long-term interim storage. The CSB will provide safe handling and dry storage for the SSFCs containing the BFAs.

The purpose of this document is to describe the SSFC system and interface equipment, including the technical basis for the system, design descriptions, and operations requirements. It is intended that this document will be periodically updated as more equipment design and performance specification information becomes available.

\subsection{SHIPPINGPORT SPENT FUEL CANISTER SYSTEM SUMMARY DESCRIPTION}

\subsection{SHIPPINGPORT SPENT FUEL CANISTER BOUNDARIES}

The SSFC is a passive storage system for the Shippingport PWR Core 2 BFAs. Based on economic and technical considerations, the SSFC will use the Spent Nuclear Fuel (SNF) Project's multi-canister overpack (MCO) design, with minor modifications to accommodate differences between the PWR Core 2 BFAs and the design basis payload for the MCOs (i.e., N Reactor SNF). The canister, shown in Figure 1, has approximate dimensions of 24 in. in diameter and 157 in. long without the cover cap installed. The canister has a welded bottom closure and a 10-in. long forged collar at the top with a maximum diameter of $25.310 \mathrm{in}$., which provides the connecting surfaces for a locking and lifting ring and a 12-in. thick shield plug with a mechanical seal. The SSFC and all major components are constructed of stainless steel. Provisions are also provided for a welded closure cap to be installed after receipt at the CSB. 
Each SSFC will be loaded with 4 BFAs at the T-Plant; therefore, a total of 18 SSFCs will be required to store the 72 BFAs that are currently in pool storage. Spacing of the BFAs within the SSFC cavity is accomplished using a circular insert that is divided into four quadrants and placed into the SSFC prior to delivery of the SSFC to the Hanford Site. A two-piece fuel-loading guide placed onto the top opening of the SSFC protects the screw threads on the SSFC collar and the shield plug gasket-sealing surface from damage during loading of the BFAs. When loading of the BFAs is complete, the fuel-loading guide portion is removed (leaving the shield plug guide portion inserted), the SSFC shield plug is installed, and the shield plug guide is removed.

The SSFC collar provides for a threaded shield plug locking and lifting ring that is inserted and rotated until securely in place. The locking and lifting ring closure tool has the capability for applying downward pressure on the shield plug and seal, which compresses the seal and allows the set screws in the locking and lifting ring to be easily tightened. When the closure tool is removed, the set screws apply pressure to the shield plug seal thereby completing the leak tight closure system for transport to the CSB. The shield plug is provided with a port and offset penetration (to minimize radiation streaming to the operators), which is used for vacuum drying the loaded BFAs and for backfilling the SSFC with inert gas through a threaded port plug valve with metallic seal. A bolted port cover plate with gasket is provided to seal the port opening. In subsequent operations, the port cover plate and shield plug seal are leak tested. The final containment barrier for the SSFC long-term storage is a cover cap that will be welded to the canister shell collar at the CSB.

\subsection{BLANKET FUEL ASSEMBLIES}

A schematic of the BFAs showing the fuel plates and top and bottom extension brackets is provided in Figure 2. Except for minor differences in the top and bottom extension brackets, each of the BFAs are of the same design and are about $144 \mathrm{in}$. long and slightly over $7 \mathrm{in.} \mathrm{square.} \mathrm{The}$ top and bottom extension brackets are bolted to the fuel clusters. The fuel cluster plate is constructed of numerous high-density natural uranium-dioxide wafers placed in Zircaloy-4 cladding. The extension brackets are made of nuclear grade 304 stainless steel. After nine years of irradiation, the BFAs contain fission and decay products, and quantities of actinides such as plutonium, americium, and curium. The BFAs that were located adjacent to the reactor seed (driver) assemblies are higher burnup, first-pass assemblies that attained maximum burnup. The second-pass assemblies attained a burnup of about $60 \%$ or less than the maximum burnup assemblies.

The overall dimensions and construction of the BFAs have been confirmed by comparison to Westinghouse Bettis Atomic Laboratory drawings and physical examination of an unirradiated assembly. From all indications, the BFAs are in excellent condition with no apparent corrosion deterioration or cladding failure and no appreciable crud deposits of concern. 


\subsection{SHIPPINGPORT SPENT FUEL CANISTER INTERFACES}

\subsubsection{Procurement}

The SSFC design is an exact duplication of the MCO, except for shield plug modifications that do not impact the basic parameters of $\mathrm{MCO}$ fabrication. Therefore, the selection of the modified MCO design for the required 18 SSFCs allows for procurement, via an amendment to the existing contract for fabrication of the $400 \mathrm{MCOs}$, with very little perturbation to the fabrication process. This cost-effective procurement is allowable because the requirements for confinement of the Shippingport PWR Core 2 BFAs are bounded by the more rigorous requirements imposed on the $\mathrm{MCO}$ design. This interface will require coordination with the MCO Fabrication Project during the acquisition of the SSFCs.

A design of the canister insert is being provided for supporting the Shippingport PWR Core 2 BFAs within the SSFC shell. This insert acts as a guide for loading four BFAs into an SSFC shell at the T-Plant.

\subsubsection{Storage and Transfer to Site Facilities}

Once received on-site, there is a storage interface for the SSFC components. The canister inserts will be fabricated separately but preinstalled in the SSFC at the vendor plant. The SSFC shell, with the insert and locking and lifting ring in place and a plastic cover over the shell opening, is received as a package. The shield plug (with the cover plate installed and no seals) is packed on a pallet and the shield plug Helicoflex' metallic seal, the canister cover cap, and the shield plug components (including the port cover plate seals) are separately packaged for shipment from the SSFC fabricator. The canister, including all components and the inserts, will be inspected by the vendor and green tagged at shipment. When received at the Hanford Site, the packages will be checked for damage and the green tags will be verified against inspection records. All items will then be transported to temporary on-site storage or the point of use and unpacked.

\subsubsection{Cask Transport Trailer}

The SSFC shell, with the insert inside and the locking and lifting ring temporarily in place, is transported to the CSB, where it is stored until it can be installed in an empty transport cask. The cask is then loaded onto a transporter. This cask-SSFC transporter interface is maintained for transfer to the T-Plant, during SSFC loading, and transfer back to the CSB for unloading the SSFC filled with BFAs. The cask transport trailer also provides a work platform for loading activities at the T-Plant and receipt activities at the CSB. There are no modifications to the cask transport trailer for transport of the SSFCs.

\footnotetext{
'Helicoflex is a trademark of Cefilac, Societe Anonyme.
} 


\subsubsection{T-Plant}

The shield plugs with the port cover plate installed, Helicoflex seals, and other components (e.g., process port plug seals, cover plate seals, cask seals and all spares) are transported to the $277 \mathrm{~T}$ staging area at the T-Plant. After transporter positioning in the T-Plant railroad tunnel, the cask lid is removed and stowed, the locking/lifting ring is removed from the SSFC shell, and the two-piece fuel-loading guide is installed. Following loading of four BFAs into the canister, the shield plug and the locking and lifting ring are installed, and the locking and lifting ring is tightened. Handling and installation of the shield plug and the locking and lifting ring require special tools to interface with T-Plant cranes and the SSFC. The removal and replacement of the cask lid also interfaces with T-Plant cranes and requires the use of special handling and closure tools.

Contamination control must be provided for the outside surface of the SSFC, the cask, and the transport trailer, including the work platform. Also, during the transfer of the BFAs from the T-Plant storage pool to the SSFC, the portion of the SSFC collar that seats the shield plug seal must be protected against damage and dirt.

After the shield plug and the locking and lifting ring are installed, the shield plug port cover plate is removed and the process port connector is bolted to the cover plate opening in the shield plug. A flexible hose from the drying and backfill system is then attached to the port connector. Following vacuum drying and helium backfilling, the port cover plate (with seal in place) is installed and leak tested. As a final step, the shield plug and port seals are leak tested by installing a hood over the top of the SSFC and drawing a vacuum through a helium mass spectrometer leak detector (MSLD). This equipment interfaces with the T-Plant cranes and the T-Plant railroad tunnel for power to the vacuum pump, the trace heating for the drying and inerting system filter(s), and the helium MSLD system. A helium supply manifold is provided for the drying and inerting system skid, and compressed air is also provided for the locking and lifting ring closure and cask torqueing tools.

\subsubsection{Canister Storage Building}

The SSFC interfaces at the CSB are about the same as for the MCO, except that the cask is not pressurized and the enclosure and filtering system is not required to be installed for opening the cask in the service pit (and cask lid removal). None of the SSFCs require sampling. When the welding station is available, the MCO handling machine (MHM) can transfer the SSFC for welding of the cover cap. Before the welding operation can be performed with the SSFC, a cover cap must be received at the CSB from the SSFC components storage area. An interface difference between the MCO and the SSFC that impacts the MHM is that the SSFC is about onehalf the weight of the $\mathrm{MCO}$, which will require set point changes in the MHM weight-sensing interlocks. 


\subsection{SAFETY AUTHORIZATION BASIS}

The TN-WHC transportation cask that will be used to transport the SSFC is the same as the MCO cask. The safety authorization basis for the transportation of SSFCs in the transportation cask is to be documented in a revision to HNF-SD-TP-SARP-017, Safety Analysis Report for Packaging (Onsite) Multicanister Overpack Cask.

For SSFC storage in the CSB, the CSB Final Safety Analysis Report (FSAR) is being amended to address any new requirements for the SSFCs, which will be documented in HNF-3553, Annex A, Addendum A, "Shippingport PWR Core 2 Fuel Storage at Canister Storage Building." The methodology being employed is to provide a comparison to the different requirements for storage of the MCOs and evaluate any requirements that change for the SSFCs. In most cases, the SSFC requirements are bounded by N Reactor fuel in the MCOs and are expected to have a minor impact on the CSB FSAR.

At the T-Plant, the authorization basis will either be a revision or addendum to the existing Interim Safety Basis (ISB) or a separate safety analysis report. The existing authorization basis is documented in HNF-SD-WM-ISB-006, Interim Safety Basis for Solid Waste Facilities (T-Plant).

\subsection{SYSTEM CLASSIFICATION}

The safety classification of all structures, systems, and components (SSCs) related to the SSFC is addressed in Addendum A to the CSB FSAR (HNF 3553, Annex A). The safety classification process for the CSB uses guidance from HNF-PRO-704, Hazard and Accident Analysis Process of DOE-STD-3009-94, and applies the graded approach methodology of DOE-STD-3009-94, Preparation Guide for U. S. Department of Energy Nonreactor Nuclear Facility Safety Analysis Reports. Classification of a confinement system as safety class, safety significant, or general service depends on the preventative, mitigative, or worker safety SSC function for reducing adverse effects on the environment, the public, on-site workers and facility workers. There are no postulated releases with consequences exceeding off-site guidelines for the CSB, as shown in Chapter AA3.0 of HNF-3553. Therefore, no CSB SSCs are required to have a safety-class confinement function as a result of the introduction of Shippingport PWR Core 2 BFAs in SSFCs. The SSFC is considered safety-significant for confinement during storage. There are no safety-class criticality control functions as the blanket fuel has insufficient fissile content to sustain a criticality.

\subsection{TECHNICAL BASES}

\subsection{FUNCTIONAL AND PERFORMANCE REQUIREMENTS}

The SSFC functional requirements are based on U.S. Nuclear Regulatory Commission (NRC) equivalency for dry storage of PWR and boiling water reactor fuel. The major aspects of 
NRC equivalency and specific performance requirements are discussed in the subsections that follow.

\subsubsection{Containment}

The SSFC provides the capability to receive Shippingport PWR Core 2 BFAs from the T-Plant, condition the BFAs, maintain an inert atmosphere during transport and storage of the BFAs, and continue to provide containment during normal operations. For dry storage conditions, experimental data have not demonstrated an acceptably low oxidation rate for $\mathrm{UO}_{2}$ spent fuel over the licensing period to permit safe storage in an air atmosphere. A non-reactive environment is required to protect fuel assemblies against fuel cladding degradation that might otherwise lead to localized cladding pinholes and oxidation of the uranium-dioxide wafers to form less-dense $\mathrm{U}_{3} \mathrm{O}_{8}$, which could cause clad rupture (PNL-6365). To reduce the potential for fuel oxidation and subsequent cladding failure, a helium inert atmosphere cover gas has been used commercially and has been accepted by the NRC. Measures for providing a non-reactive environment within the SSFC include vacuum drying to remove water from the loaded BFAs and in the process removing the air atmosphere, and then backfilling with helium.

\section{Fuel Drying}

The SSFC system accomplishes fuel drying consistent with NRC-accepted methods described in NUREG-1536, Standard Review Plan for Dry Cask Storage Systems. The NRC staff has accepted vacuum drying methods comparable to those employed in the cask performance testing for cover gas compositions reported in PNL-6365, Evaluation of Cover Gas Impurities and Their Effects on the Dry Storage of LWR Spent Fuel, for commercial light water reactor (LWR) fuel. This report evaluates the effects of oxidizing impurities on the dry storage of LWR fuel and recommends a limiting maximum quantity of oxidizing gases (e.g., $\mathrm{O}_{2}, \mathrm{CO}_{2}$, and $\mathrm{CO}$ ) of $0.25 \% \mathrm{vol}$. This limit reduces the amount of oxidants below levels where any significant degradation of the Zircaloy cladding is expected.

Moisture removal is inherent in the vacuum drying procedure. Evacuation at or below the pressure evaluated in PNL-6365 (i.e., $0.4 \mathrm{kPa}$ [3.0 mm Hg or torr]) demonstrates that air and moisture removal is adequate to assure oxidants available to contaminate the cover gas are below values that could cause cladding degradation. Therefore, the drying and inerting system design is capable of evacuating the SSFC cavity to less than $0.4 \mathrm{kPa}(3.0 \mathrm{~mm} \mathrm{Hg}$ or torr). After initial evacuation to less than 3 torr and backfilling with helium, the canister is evacuated a minimum of one more time. Before final backfill, a pressure rebound test is performed to demonstrate adequate moisture removal.

The drying and inerting system design/operation reflects the potential for blockage of the moisture removal pathway(s) as a result of icing during evacuation. Icing can occur from the cooling effects of water vaporization and system depressurization during evacuation of the SSFC. Icing is more likely to occur in the evacuation system lines than in the canister because of decay heat from the fuel. A staged draw down or other means of preventing ice blockage of the canister evacuation path will be used. 
If the BFAs within the SSFC are held under vacuum for an extended period of time, the decay heat transfer is limited, and the temperature of the BFAs will slowly rise. Calculations of the rate of BFA moisture removal and temperature rise under vacuum will be used to determine acceptable SSFC process parameters.

\section{Canister Inerting}

The system provides for canister inerting consistent with the NRC-accepted method. Upon completion of fuel drying and canister evacuation, the canister will be backfilled with helium. The system allows re-evacuation and re-backfilling with helium and is designed to allow sampling before final closure, if required. In order to achieve helium purity requirements, the system design will be compatible with a helium-quality specification that ensures a known maximum of impurities that will minimize the source of contaminants. The recommended helium purity specification to achieve this requirement is $99.9 \%$ helium, although the purity of typical vendor-supplied helium is $99.997 \%$.

The capability for repetition of the evacuation and repressurization cycles is provided by the drying and inerting system. This capability is necessary if the canister interior is opened to an oxidizing atmosphere following the evacuation and repressurization cycles (as may occur in conjunction with seal repairs, etc.).

Upon completion of canister loading, drying, and inerting, the system is capable of verifying that the gas fill of the canister interior is at a pressure level that is expected to maintain a non-reactive environment for at least the 40 -year storage life of the canister interior, under both normal and off-normal conditions and events. The NRC has previously accepted specifications that incorporate an overpressure of approximately $14 \mathrm{kPa}(\sim 2 \mathrm{psig})$ and container leak testing as conditions of use for satisfying this requirement.

Additional performance requirements for the fuel drying and canister inerting system are provided in HNF-3043, Performance Specification, Fuel Drying and Canister Inerting System for Shippingport Pressurized Water Reactor (PWR) Core-2 Blanket Fuel Assemblies Stored Within Shippingport Spent Fuel Canisters.

\section{Criticality}

No specific analyses were performed for the SSFCs containing the Shippingport BFAs (HNF-SD-SNF-CSER-005). These assemblies were fabricated using natural $\mathrm{UO}_{2}$. The actinide masses in a Shippingport Core 2 BFA are shown in Table 1, and for the maximum burnup does not exceed $0.90 \mathrm{wt} \%{ }^{239} \mathrm{Pu}$. Dry mixed oxides of plutonium and uranium with enrichments less than $3 \mathrm{wt} \%$ are subcritical in any amount (ANSI/ANS 8.12), and storage of the dry SSFCs in the CSB is acceptable without safety-class components or special controls. 
Table 1. Actinide Masses in Shippingport Core 2 Blanket Fuel Assemblies as a Function of Burnup and Decay Date of January 1, 2001.

\begin{tabular}{|c|c|c|}
\hline \multirow{2}{*}{$\begin{array}{c}\text { Nuclide } \\
\text { (grams) }\end{array}$} & \multicolumn{2}{|c|}{ Fuel Exposure During Reactor Irradiation ${ }^{(\mathbf{})}$} \\
\cline { 2 - 3 } & $\mathbf{1 3 , 8 0 0} \mathbf{M W}_{\mathbf{t}} \mathbf{d} / \mathbf{M T U}$ & $\mathbf{2 4 , 6 0 0} \mathbf{M W}_{\mathbf{t}} \mathbf{d} / \mathbf{M T U}$ \\
\hline${ }^{235} \mathrm{U}$ & 555.9 & 247.0 \\
\hline${ }^{236} \mathrm{U}$ & 179.0 & 214.4 \\
\hline${ }^{238} \mathrm{U}$ & 219,700 & 216,500 \\
\hline${ }^{237} \mathrm{~Np}$ & 35.97 & 57.70 \\
\hline${ }^{239} \mathrm{Pu}$ & 1,080 & 1,146 \\
\hline${ }^{240} \mathrm{Pu}$ & 364.1 & 535.9 \\
\hline${ }^{241} \mathrm{Pu}$ & 63.06 & 88.28 \\
\hline${ }^{241} \mathrm{Am}$ & 193.5 & 270.1 \\
\hline${ }^{T o t a l}{ }^{(2)}$ & $2.223 \mathrm{E}+05$ & $2.194 \mathrm{E}+05$ \\
\hline
\end{tabular}

(1) Units are grams per assembly. Actinides with mass below 50 grams per assembly are not listed.

(2) Totals include all actinides in one assembly.

\subsubsection{Design Life}

The SSFC is designed for a 40 -year storage life.

The drying and inerting system is designed to provide a minimum of 100 fuel drying and canister inerting cycles without component failure or with features to allow quick replacement of components likely to fail.

\subsubsection{Design Basis Capacity}

The SSFC is designed to contain four Shippingport PWR Core 2 BFAs.

When a BFA is removed from the T-Plant pool, some amount of water may be captured in the cavity of the top extension bracket. While the assembly is still over the pool, most of this water is removed by siphoning, pumping, aerating, or some other engineered method. The BFA will be held above the pool for about one hour to allow water to evaporate from the surface and to minimize potential water dripping during the SSFC loading operation. Free water remaining in the fuel assembly component geometry is minimal. A small amount of water is expected to be retained by adhesion to the fuel plate surfaces in the 0.091 -in. water channels between fuel plates, the 0.062-in. gap between the outer fuel plates and end channels, and on the surfaces of the top and bottom BFA extension brackets. 
The drying and inerting system is designed to service a single SSFC at a time. The quantity of water to be removed from each SSFC by drying is nominally 0.65 gals ( 2.5 liters). Calculations supporting the nominal amount of free water in a BFA are provided in HNF-3043, Attachment 1.

\subsection{SPECIFICATIONS}

To perform its safety functions under normal conditions, the SSFC is required to remain structurally stable and not leak. It must also retain its integrity as a boundary for retention of the inert gas atmosphere. The SSFC also provides confinement of the BFAs.

NRC requirements for a Title 10, Code of Federal Regulations, Part 72 (10 CFR 72), "Licensing Requirements for the Independent Storage of Spent Nuclear Fuel and High-Level Radioactive Waste," licensed facility would allow for application of either Subsection NB or NC, 3.IV.1.b(1)(b) of the American Society of Mechanical Engineers (ASME) Boiler and Pressure Vessel Code (ASME Code) (ASME 1995). The SSFCs have the same structural design as the $\mathrm{MCO}$, and the MCOs have been manufactured and code stamped in accordance with the ASME Code, Section III, Subsection NB, "Class 1 Components" (ASME 1998).

Specifications for the canister, shield plug, and insert are provided in SNF-5133, Shippingport, Spent Fuel Canister Design Report, SNF-5191, Shippingport Spent Fuel Canister and Shield Plug Fabrication Specification, and SNF-5192, Shippingport Spent Fuel Canister Insert Fabrication.

\subsection{SYSTEM AND PROCESS EQUIPMENT DESIGN DESCRIPTION}

\subsection{SHIPPINGPORT SPENT FUEL CANISTER SYSTEM}

Design descriptions of various SSFC components and interfacing equipment are described in the subsections that follow.

\subsubsection{Canister Shell}

The SSFC package is an SSFC assembly loaded with four Shippingport BFAs. The SSFC has been designed to allow insertion and removal from the TN-WHC transportation cask (MCO transfer cask).

The SSFC assembly is a single-purpose SNF container that is capable of maintaining confinement after having been closed and sealed. The SSFC assembly consists of a shell, a shield plug, a locking and lifting ring, and an insert to facilitate the loading of the Shippingport PWR Core 2 spent fuel. 


\section{SNF-5809, REV 0}

The following modifications to the original MCO design were accomplished to establish the design of the SSFC:

- No modification of the shell assembly was required, such that the SSFC shell and MCO shell are identical. The SSFC shell is fabricated from type 304/304L stainless steel. The SSFC shell is a cylindrical vessel that provides access to its cavity through its top end and receives a shield plug assembly at its top end for closing. The SSFC shell has a bottom assembly that provides a welded closure on the shell bottom end. The SSFC bottom assembly is nominally flat and includes a guide cone (internal liquid collection sump in the MCO) at the SSFC centerline required for centering the SSFC PWR Core 2 insert within the SSFC shell. The SSFC allows for loading the canister insert within its cavity. The empty shell is designed to load into and out of the transport cask using the locking and lifting ring, without the shield plug installed.

- The SSFC has the same mechanical closure configuration as the MCO. The closure relies on a mechanical elastic/crushable metallic seal to maintain the confinement requirement. The closure system uses the shield plug/shell interface as the closure boundary where the crushable metallic seal is located. The shield plug is held in place via a locking and lifting ring threaded into the SSFC shell. The locking and lifting ring contains screws that, when tightened, hold the shield plug down against the elastic/crushable metallic seal while pushing up on the locking and lifting ring.

- The SSFC shell is designed to incorporate a final welded closure cap over the shield plug. The cap is welded to the SSFC shell, and the weld geometry permits $100 \%$ ultrasonic examination of the weld. The final seal/shell structure weld is ASME Code-qualified such that the ASME N Stamp is preserved for the assembly structure. The cap is configured for lifting the SSFC with the same equipment currently provided for the locking and lifting ring. The cap shall be capable of withstanding the design pressure rating of $450 \mathrm{psi}$ at $132^{\circ} \mathrm{C}$.

The overall dimensions of the SSFC are 24 in. in diameter by 160 in. in height with the shield plug and locking and lifting ring installed. The wall thickness is 0.5 in. The shell is welded to a stainless steel bottom forging that is 24 in. in diameter. The cylindrical shell, bottom assembly, canister collar, shield plug, and locking and lifting ring form the primary pressureretaining boundary for the SSFCs.

From loading at the T-Plant to placement in interim storage, the interior of the SSFC is exposed to three distinct thermal-hydraulic conditions: filled with BFAs containing moisture in an air atmosphere, in vacuum or near-vacuum conditions, and dried and backfilled with helium gas. While at T-Plant, the SSFC will experience all three distinct operating conditions. The SSFC is constructed from austenitic stainless steel with high resistance to corrosion from all aspects of the environment to which the system is expected to be exposed during its lifetime.

\subsubsection{Shield Plug and Locking and Lifting Ring}

The shield plug is a multifunctional component of the SSFC that provides a mechanical confinement boundary until the SSFC cover cap is welded in place. The shield plug also provides 
for axial radiation shielding to allow personnel access to the top of the SSFC for closing the SSFC and for performing the vacuum drying, helium backfilling, and leak checking processing functions, and during welding operations at the CSB. The shield plug retains the main seal, which seals between the SSFC collar and the shield plug.

MCO shield plug modifications increase the cavity length within the SSFC in order to accommodate the length requirement for the Shippingport PWR Core 2 BFAs. Since the SSFC does not include requirements for removal of bulk water or internal infiltration, it has been determined that the additional cavity length can be obtained through modification of the MCO shield plug by removal of these capabilities, thereby requiring no modification of the canister shell assembly.

A 12-in. thick shield plug that is inserted into the top of the SSFC is shown on Figure 3. The shield plug was modified to allow for increased cavity length by removing the filter assembly, and the guard plate, guard plate ring, and center process tube on the MCO shield plug. Since the Shippingport fuel is loaded dry, only one port penetration is required for cavity evacuation and backfill with helium. Therefore, the shield plug was modified to have only a single port that connects to the interior cavity of the SSFC. Elimination of the other three penetrations used for MCO processing increases shielding, thereby accomplishing ALARA (as low as reasonably achievable) considerations. Also, the removal of the unnecessary shield plug components provided enough cavity space inside the SSFC to provide an additional 2 in. of shielding material to the bottom of the shield plug. A cross-sectional view of the shield plug showing the port pathway can be seen in Figure 3.

The SSFC shield plug attaches to the SSFC shell assembly in the same way as the MCO shield plug in an MCO. A threaded assembly called the locking and lifting ring holds the shield plug into the SSFC shell. The locking and lifting ring assembly threads into the SSFC collar with a double lead buttress thread. Once the locking and lifting ring is installed, a hydraulic ram on the locking and lifting ring closure tool generates a force that compresses the metal Helicoflex seal, after which the 18 1.5-in. diameter set screws are tightened. The set screws maintain a minimum sealing load. The metallic seal can only be installed once and not reused. Materials of construction for the SSFC collar, locking and lifting ring, and set screws are chosen to avoid component galling and will be in accordance with the specifications in SNF-5133.

The locking and lifting ring features an integrally machined axisymmetric lifting ring (see Figure 3 ) with a 12 -ton lifting capacity, when gripped with six equally spaced grippers. The ring facilitates handling of the SSFC at the CSB.

\subsubsection{Insert}

A new canister insert is provided for supporting the BFAs within an SSFC. The insert is designed to use the bottom support and guide cone of the SSFC shell for positioning and to not require attachment to the shell. No modification of the SSFC shell is required. The insert is not designed to provide any physical support of the BFAs for criticality geometry control (not required) or shielding purposes after loading. The insert guides the BFAs into each quadrant as they are loaded into the SSFC with the insert in place. 
The SSFC fuel insert has a circular base plate that is $3 / 4$-in thick by $22.25 \mathrm{in}$. in diameter. The bottom outer circumference has a $1 / 4 \times 45$ degree bevel. There are four 0.25 -in. thick vertical ribs that divide the cylindrical cavity of the SSFC into four quadrants. The outer radius of these quadrants is the inner surface of the SSFC shell. The overall height of the insert is $135 \mathrm{in}$. The design of the insert uses the bottom support and guide cone of the SSFC shell for centering by providing a 2.525 -in. clearance hole in the bottom plate of the insert that rises 3 in. into the vertical ribs. The insert is a guide for fuel loading and provides no physical support of the Shippingport PWR Core 2 fuel assemblies other than the bottom plate that the fuel assembly bottom nozzle rests on.

The insert is divided into four compartments, each of which holds one BFA. The insert clearance between a compartment segment and the opening of the fuel-loading guide allows for up to $1 / 2$ in. of bowing in the fuel assembly in any direction.

\subsubsection{Blanket Fuel Assemblies}

The overall design of the BFAs is shown in Figure 4 and Figure 5. Specific dimensions and physical characteristics of the PWR Core 2 BFAs (WAPD-296) are listed in Table 2.

The fuel cluster consists of two identical uranium dioxide Zircaloy-4 fuel plate subassemblies welded together to form a square structure, with two Zircaloy-4 cluster extensions welded to the ends of the subassemblies. Each of the subassemblies consists of 30 compartmented fuel plates containing numerous high-density uranium dioxide fuel wafers. The wafers were coated with pyrolytic carbon that prevents the Zircaloy-4 cladding from reacting with the uranium dioxide. The gap between the plates on the inside of the BFAs is quite small, 0.091 in., which could be reduced in various locations due to fuel plate bowing. Also, the gap between the fuel plate and the Zircaloy- 4 outer shell at the outer edge is 0.062 in. These small gaps, with an expected slightly roughened surface caused by autoclaving of the Zircaloy in the reactor, may lead to retention of small quantities of water on the plate surface. However, use of evacuation to remove water is expected to be effective, and the time required for water removal will be determined by testing.

Recent source term calculations using the ORIGEN2 computer code (HNF-SD-SNF-TI-061) have conservatively corrected Zircalloy 4 hafnium content and calculated 2001 values for fission and activation products. The high burnup level was calculated to be $24,600 \mathrm{MW}_{\mathrm{t}} \mathrm{d} / \mathrm{MTU}$. Based on records of the amount of plutonium in each assembly, the BFAs can be divided into various categories of estimated burnup, as shown in Table 3 . These estimated burnups and the number of assemblies in each burnup category will be used to develop an SSFC loading plan. As can be seen in Table 3, seven of the BFAs attained the highest burnup level of $24,600 \mathrm{MW}_{\mathrm{t}} \mathrm{d} / \mathrm{MTU}$. Rather than recalculate the average burnup of $16,000 \mathrm{MW}_{\mathrm{t}} \mathrm{d} / \mathrm{MTU}$ previously calculated, a "nominal" burnup of $13,800 \mathrm{MW}_{\mathrm{t}} \mathrm{d} / \mathrm{MTU}$ was used. This represents a basis for the maximum dose for one-half of the canisters, using a loading plan that will minimize operator radiation exposure. 
Table 2. Physical Characteristics of the Shippingport Pressurized Water Reactor Core 2 Blanket Fuel Assemblies.

\begin{tabular}{|c|c|}
\hline Type of assembly & Plate type of blanket fuel \\
\hline Type of blanket fuel & High density, natural $\mathrm{UO}_{2}$ wafers \\
\hline \multicolumn{2}{|l|}{ Composition of fuel assemblies: } \\
\hline Fuel cladding and assembly shell & Zircaloy-4 \\
\hline Top extension bracket & Type 304 stainless steel \\
\hline Bottom extension bracket & Type 304 stainless steel \\
\hline Bottom extension bracket spring & Inconel-X \\
\hline \multicolumn{2}{|l|}{ Blanket fuel assembly dimensions: } \\
\hline Overall length of fuel assemblies & $142-5 / 16$ inches \\
\hline Top extension bracket & $18-1 / 2$ inches \\
\hline Upper square section (7-1/2 inches $\times 7-1 / 2$ inches) & $6-1 / 4$ inches \\
\hline $\begin{array}{l}\text { Cylindrical section (5-3/4 inches diameter; includes } \\
\text { transition) }\end{array}$ & 10 inches \\
\hline Lower square section (7-3/8 inches $\times 7-3 / 8$ inches) & $2-1 / 2$ inches \\
\hline Core region ( $7-3 / 8$ inches $\times 7-3 / 8$ inches) & 104-1/2 inches \\
\hline Bottom extension bracket & $19-5 / 16$ inches \\
\hline Upper square section ( $7-3 / 8$ inches $\times 7-3 / 8$ inches) & $2-27 / 32$ inches \\
\hline $\begin{array}{l}\text { Cylindrical section (5-3/4 inches diameter; includes } \\
\text { transition) }\end{array}$ & $8-29 / 32$ inches \\
\hline Lower $4-1 / 8$ inch diameter section & Approximately $7-1 / 2$ inches \\
\hline Blanket assembly weight (each) & 1,180 pounds \\
\hline Blanket assembly bow (WHC-SD-WM-ES-394) & $<1 / 2$ inches \\
\hline \multicolumn{2}{|c|}{ Calculated maximum heat per assembly (HNF-SD-SNF-TI-061): } \\
\hline With decay to 1999 & 165 watts \\
\hline With decay to 2001 & 158 watts \\
\hline \multicolumn{2}{|c|}{ Calculated maximum fuel surface temperature with decay to 1999 (HNF-4109): } \\
\hline In air & $210^{\circ} \mathrm{C}\left(410^{\circ} \mathrm{F}\right)$ \\
\hline In helium & $169^{\circ} \mathrm{C}\left(336^{\circ} \mathrm{F}\right)$ \\
\hline $\begin{array}{l}\text { Calculated maximum canister temperature (HNF-4109) } \\
\text { in helium }\left(60^{\circ} \mathrm{C}\left[140^{\circ} \mathrm{F}\right] \text { ambient): }\right.\end{array}$ & $136^{\circ} \mathrm{C}\left(277^{\circ} \mathrm{F}\right)^{(1)}$ \\
\hline $\begin{array}{l}\text { Maximum canister temperature adjusted to } 2001 \text { heat } \\
\text { load }\left(158 \text { watts } / 165 \text { watts } \times 136{ }^{\circ} \mathrm{C}\left[277^{\circ} \mathrm{F}\right]\right) \text { : }\end{array}$ & $130.3^{\circ} \mathrm{C}\left(267^{\circ} \mathrm{F}\right)^{(1)}$ \\
\hline $\begin{array}{l}\text { Estimated mid-canister average temperature in helium } \\
\left(60^{\circ} \mathrm{C}\left[140^{\circ} \mathrm{F}\right] \text { ambient): }\right.\end{array}$ & $100^{\circ} \mathrm{C}\left(212^{\circ} \mathrm{F}\right)^{(1)}$ \\
\hline
\end{tabular}

(1) These calculations were performed with maximum Canister Storage Building storage tube ambient conditions for a canister misloaded with four maximum burnup assemblies and 1.5 peak-to-average axial power distribution. 
Table 3. Estimated Burnup and Number of Shippingport Blanket Fuel Assemblies in Each Burnup Category Based on Available Plutonium Buildup Records.

\begin{tabular}{|c|c|c|}
\hline Plutonium Buildup, $g$ & $\begin{array}{c}\text { Estimated Burnup, } \\
\text { MW,d/MTU }\end{array}$ & No. of Assemblies \\
\hline 2280 & $24,600^{(1)}$ & 7 \\
\hline 2246 & 22,000 & 4 \\
\hline 2125 & 20,800 & 4 \\
\hline $1990 / 1975$ & 19,400 & 10 \\
\hline 1838 & 18,000 & 1 \\
\hline 1794 & 17,600 & 7 \\
\hline 1703 & 16,700 & 4 \\
\hline $1458 / 1428$ & 14,300 & 15 \\
\hline $1290 / 1286$ & 12,600 & 11 \\
\hline $1102 / 1072$ & 10,800 & 9 \\
\hline
\end{tabular}

(1) Highest level of burnup calculated for the maximum burnup assemblies using ORIGEN2 computer code.

A total of fifteen BFAs, which is less than the number of SSFCs, have a burnup greater than 20,000 MW $\mathrm{d} / \mathrm{MTU}$ (see Table 3). Therefore, to establish ALARA dose rates, it is required that these high burnup assemblies will be distributed so that only one of these assemblies will be loaded in any SSFC. Also, there are 20 BFAs that have a burnup below $13,800 \mathrm{MW} \mathrm{d} / \mathrm{MTU}$. The SSFC loading plan will provide for placing an assembly with the lowest burnup diametrically opposite the high burnup assembly so that there will be an identified low dose position on the cask where an operator can perform tasks where the dose rate is minimal. A significant number of intermediate burnup BFAs will be located in the positions adjacent to the low burnup assemblies in the SSFCs that will need to be addressed in the loading plan to keep operator exposure to a minimum. The maximum burnup of the assembly in the low dose position is conservatively estimated to be about $13,800 \mathrm{MW} d / \mathrm{MTU}$.

One Shippingport fuel assembly was examined for surface deposits (WAPD-335) and the crud thickness was found to be $<0.5$ mils at the plate ends, with no discernable crud in the midregion. Analysis of de-scaled crud in 1977 (Benz 1977) indicated crud activities on the order of $10^{-4} \mathrm{Ci} / \mathrm{dm}^{2}$ for cobalt-60 and iron -65 , and $10^{-5} \mathrm{Ci} / \mathrm{dm}^{2}$ for nickel-63. During storage in the T-Plant pool, there has been no indication of loose crud from the fuel presence in the water. In addition, due to the design of the BFAs, any loose crud on the surface of the many plates is not anticipated to be of any consequence because the plates are almost entirely contained by the outer shell Zircaloy plates of the fuel assemblies. Therefore, from all indications, there is no reason to expect any spread of contamination from handling the BFAs during loading in the SSFCs and 
during evacuation and helium backfilling processing. Filtration will be provided in the line leading from the SSFC to the drying and inerting system to avoid any potential for particulate carryover.

It was reported in 1977 (Howard 1977) that corrosion effects in the BFAs were negligible for all practical fuel handling purposes. The cladding thickness on the Shippingport PWR Core 2 blanket assemblies, at that time, still conformed to as-built tolerances. Therefore, there is no reason to expect any structural weaknesses related to corrosion for lifting and handling the BFAs.

\subsection{SHIPPING CASK}

The TN-WHC transportation cask used for transport of the SSFCs is a vertical, cylindrical, stainless steel vessel. The cask has an outside diameter of $39.81 \mathrm{in}$. and a height of 170.25 in. The overall packaging assembly, including the lifting device, has an outside diameter of $43.83 \mathrm{in}$. and an overall height of $190.25 \mathrm{in}$. The cask cavity diameter is $25.19 \mathrm{in}$. and is 160.50 in. deep. The cask consists of a forged 7.31-in. thick, 170.25-in. long, stainless steel cylinder with an integrally welded stainless steel bottom head that is 6.13 in. thick. A quickdisconnect fitting is positioned near the bottom of the cask that communicates with the interior cavity. This safety-class fitting provides connection with the cask-MCO annulus and is protected with a port cover when not in use. This water drain port will not be used for transport of the SSFCs, as they are loaded dry.

The transportation cask is a Category 1 package (NRC Regulatory Guide 7.11, Table 1). Therefore, NUREG/CR-3854, Fabrication Criteria for Shipping Containers, indicates that the design, fabrication, and testing of the cask containment boundary are performed to the intent of the requirements of the ASME Code, Section III, Subsection NB, "Class 1 Components" (ASME 1998). The containment boundary design follows the criteria from Section III of the code. The structural analyses criteria meet Section III requirements. However, the cask is not code stamped.

Fabrication of the cask is in accordance with the guidelines of NUREG/CR-3854. All welds and weld joints meet NUREG/CR-3019, Recommended Welding Criteria for Use in the Fabrication of Shipping Containers for Radioactive Materials, criteria and were examined in accordance with the ASME Code, Section III, Subsection NB (ASME 1998). All containment welds are radiographed per the ASME Code, Section III, Subsection NB-5000.

Inspections and containment leak testing of the cask were performed per the ASME Code, Section III (ASME 1995), and ANSI N14.5, American National Standard for Radioactive Materials - Leakage Tests on Packages for Shipment, during fabrication.

The cask lid is forged stainless steel with a 3.5-in. thick top and 3-in. sides, an outer diameter of $35.5 \mathrm{in}$., an inner diameter of $25.5 \mathrm{in}$., and a height of $11 \mathrm{in}$. The lid has a 4-in. tall, 4.16-in. wide flange at its base, which makes the diameter of the lid 39.81 in. at the flange. The base of the lid has an O-ring groove that has an inner diameter of 31.57 in. and contains a single, butyl rubber O-ring seal that forms the confinement boundary between the cask body and lid. The interior of the base of the lid also has a 2.16-in. wide, 1.09-in. tall positioning notch that 


\section{SNF-5809, REV 0}

mates with a similar-sized extension in the cask shell. The lid is bolted to the cask body with twelve 1.5 -in. diameter bolts that are arranged on a circle with a 36.44-in. diameter. Two alignment pins that are integral to the cask body guide lid installation. Two lifting brackets are welded to the top of the cask lid and a 4-in. diameter trunnion is welded to each lifting bracket. The trunnions extend well above the top of the cask lid to facilitate lifting of the cask and the lid. The overall weight of the cask lid is approximately $2,445 \mathrm{lbs}$.

The cask also has two vent ports and one drain port. The vent ports are on the exterior of the cask lid, while the drain port is positioned low on the side of the cask body. The drain port is closed with a quick-disconnect coupling. The drain port has a cover that is bolted onto the cask with four bolts. One vent port is closed with a quick-disconnect coupling, which has a cover that is bolted onto the lid with four bolts. The other vent port is closed with a socket-head set screw and has a cover that is threaded into the lid with a "snout."

When the SSFC is positioned inside the cask, a 0.595-in. wide annulus is formed between the cask and the SSFC.

\subsection{CASK-SHIPPINGPORT SPENT FUEL CANISTER TRANSPORT TRAILER}

The transport trailer serves as a support mechanism for the cask-SSFC during BFA loading and provides a working platform for SSFC shield plug sealing operations, the vacuum drying and helium backfilling process, and SSFC leak checking. It is a three-axle trailer and is attached to a standard tractor. The trailer was procured as a commercial-grade item. A design description of the transportation cask and trailer is provided in HNF-SD-TP-SARP-017.

The trailer is disconnected from the tractor before processing activities are started at the T-Plant. The overall length of the trailer is $40 \mathrm{ft}$, its overall width is $10 \mathrm{ft}$, and its overall height with the cask in place is $17 \mathrm{ft}-6.75$ in. The trailer has a permanently attached work platform that can be used to work around the top of the cask and SSFC and provides space for manual operations on the locking and lifting ring and the shield plug, once the shield plug is in place. The trailer work platform also serves as an aid to operators for connecting hoses from the drying and inerting system and MSLD skids located on a platform that extends over the top of the trailer constructed at the end of the T-Plant railroad tunnel.

The cask tie-down system on the trailer is a fixed system, which is an integral part of the conveyance system. The conveyance system is based on a custom double-drop semi-trailer designed specifically to secure and transfer the cask. The cask is transferred in the vertical position and fits into the cask support device, an approximately 15 -in. deep well located beneath the deck of the trailer. Approximately 118 in. above the deck of the trailer, the cask is secured by a cask tie-down device mounted onto a fixed-frame constructed of structural tube members that are braced to the trailer deck with four structural tube members. The tie-down system is constructed of a rectangular, structural steel tubing (ASTM A500-96, Grade B) frame that is welded to the transport trailer bed. The cask tie-down device is designed as a hinged clamshell ring, where each half section pivots about a fixed hinge pin and is secured with three hex-head bolts. The inside diameter of the clamping ring is constructed of 6061-T6 aluminum and is 
equipped with a neoprene abrasion pad that forms a tight fit with the cask. Attached to the clamping ring are four cask hold-down brackets, equally spaced around the circumference, that restrain vertical movement of the cask.

\subsection{DRYING AND INERTING SYSTEM}

The drying and inerting system is attached to the shield plug port opening using a process port connector that is designed to seal to the shield plug flange and to open and close the shield plug port valve. A section of vacuum hose about 1 in. in internal diameter will be used to provide the pathway from the drying and inerting system manifold to the port connector. When connections are verified, the drying and inerting system is turned on and the SSFC process port plug valve is opened. Evacuation and helium repressurization cycles are then performed to eliminate moisture on the BFAs and the air atmosphere in the SSFC and replace it with helium.

The drying and inerting system module is shown schematically in Figure 6. The SSFC vacuum pump is the same type of rotary roots pump that is used for removing water from the cavity of the MCO during processing in the Cold Vacuum Drying Facility, but sized for the amount of water to be removed from the SSFC. This type of rotary pump will not introduce oil vapors into the SSFC. The vacuum pump, valves and manifold, vacuum and pressure gauges, filter(s), and a condenser and water collection tank with supporting chiller will be mounted as a modular package on a skid. At initiation of SSFC evacuation, the manual valve routed directly to the vacuum pump is closed and the bypass line through the condenser is opened. Water removed from the SSFC is condensed into a tank and held for transport to the T-Plant pool. When water condensation subsides, the bypass line valves are closed, and the valve connected directly to the vacuum pump is opened. Evacuation is continued until the pressure is sufficiently low to indicate all water has been removed (i.e., $<3$ torr).

The manifold for the drying and inerting system module is designed to provide a connection to a helium bottle manifold that will be used for SSFC backfilling. The line from the helium supply manifold to the drying and inerting system manifold will be properly safeguarded to avoid over-pressurization of the SSFC through use of a rupture disc and pressure-relief valve with low pressure settings. If gas sampling is required, the drying and inerting system manifold design will also have the capability to sample the helium gas inside the SSFC for oxidizing impurities after final helium backfilling. For this operation, the manual valves to the helium bottles and the vacuum pump are closed, and the SSFC shield plug port connector valve and manual valves to the vacuum inlet and helium sampler are opened to obtain an SSFC gas sample.

Pressure and vacuum gauges on the drying and inerting system manifold used for SSFC processing must be calibrated and capable of reading from slightly positive pressure to a very low torr range $(<3.0$ torr). Helium used for backfilling will be of sufficient purity to assure all SSFC safety and storage requirements are met. If there is a requirement for gas sampling, the gas analyzer used for SSFC gas analysis must also be calibrated prior to use. 
Certification of the processing steps, e.g., evacuation, helium backfilling, a pressure rebound test, and an SSFC helium analysis (if determined to be necessary), will be required as part of the quality assurance package that will accompany each SSFC for shipment to the CBS.

Placement of the drying and inerting system module needs to be as close as possible to the top of the SSFC to reduce vacuum loss and possible water holdup in connecting lines. When the trailer is backed into the T-Plant railroad tunnel, there is insufficient clearance on either side for process equipment. Therefore, a work platform that extends over the back end of the trailer will be constructed at the end of the T-Plant railroad tunnel. This platform will be suspended so as to provide the space required for the drying and inerting system module and the MSLD skid and also have ample space for equipment operations. In addition, the platform will provide space for the locking and lifting ring closure tool storage and calibration unit. The close proximity to the SSFC will minimize the length of hoses needed to attach to the shield plug port connector and the leak detection devices.

\subsection{LEAK CHECKING}

When the port connector is attached to the shield plug, the line to the port connector is evacuated with the shield plug port valve in the closed position. The valve to the vacuum pump is then closed and the line pressure is monitored to determine satisfactory sealing of the port connector. Following this test, the shield plug port valve is opened and the SSFC is evacuated. During the evacuation cycle, leakage within the drying and inerting system should become evident by the inability to achieve SSFC pumpdown in a pre-determined time based on process testing. Another indication of leakage may be evident when the pressure rebound test is conducted.

Upon completion of SSFC internal processing, the shield plug port valve is closed, the SSFC process port connector is disconnected, and a cover plate is installed over the shield plug port valve. The helium MSLD, mounted on a skid along with associated calibration equipment and placed on the specially constructed T-Plant railroad tunnel platform, is used for subsequent SSFC leak checking. As a first step, an MSLD leak test is performed on the shield plug port cover plate. When this operation is complete, the SSFC closure seal test fixture that is shaped like a domed metal hood is placed over the top of the SSFC using the T-Plant hoist, and a leak check of the SSFC shield plug seal is conducted. The SSFC helium MSLD tests are performed to assure that the SSFC leak rate is $<1 \times 10^{-5}$ standard $\mathrm{cm}^{3} / \mathrm{sec}$ (SNF-5133). Upon verification that the shield plug and port cover plate are leak tight, the closure seal test fixture is removed, the cask lid is replaced, and the SSFC is released for shipment to the CSB.

\subsection{SPECIAL TOOLS}

Special tools are required at T-Plant to remove and install the cask lid, remove and install the SSFC locking and lifting ring, install and remove the fuel-loading guide and shield plug guide, handle and install the shield plug, remove and insert the process port cover plate, attach and remove the process port connector, and operate the shield plug process port valve. All of 
these tools will be tested to ensure they perform their required functions. Required special tools for carrying out process operations are as follows:

- A cask lid yoke is provided to remove the cask lid before installation of the SSFC fuelloading guide and to replace the cask lid after SSFC processing is complete.

- A storage fixture is provided on the transport trailer to store the cask lid after removing it from the cask. Features for the fixture allow for the decontamination of the lid and for lid inspection and O-ring seal replacement, if necessary.

- An insert positioning tool that is used to turn the insert to the correct loading position so that a low dose BFA can be loaded in the location that will minimize operator radiation exposure.

- When BFA loading is complete, the SSFC has been sealed and leaked checked, and the cask lid has been replaced, a cask lid torque fixture that mounts to the top of the cask lid is used to tighten the cask bolts to the correct torque requirements. This is a complex fixture with special gearing, clutches, motors, and instrumentation to assure cask lid performance requirements are met. The cask lid torque fixture is stored on a cart.

- A locking and lifting ring closure tool that couples to the hoist is provided to remove the locking and lifting ring when the canister has been delivered to the T-Plant. This tool is also used to reinstall the locking and lifting ring after the BFAs have been loaded and the shield plug has been positioned in the canister opening for SSFC sealing operations. This tool has 18 rotating clamp arms that tightly engage the locking and lifting ring and two rotation lock assemblies. When the locking and lifting ring closure tool is secured, the locking and lifting ring can be turned to disengage or engage the threads on the SSFC collar. The closure tool contains a hydraulic ram that is activated to exert a downward force on the shield plug after the locking and lifting ring is installed. The downward force compresses the shield plug seal and allows the set screws to be tightened so that pressure is maintained on the seal ring and the SSFC remains sealed when the tool is removed. The locking and lifting ring closure tool is stored on a special cart or stand along with calibration equipment.

- A two-piece loading guide is placed in the canister opening to prevent damage to the canister collar threads and shield plug sealing surface during BFA loading operations. When the fuel-loading guide portion is removed, the shield plug guide portion remains over the canister opening to provide a means for preventing damage to the canister threads and sealing surface during shield plug installation on a loaded SSFC.

- A shield plug handling fixture and yoke are provided to attach to the hoist and hold the shield plug and lower it to the canister sealing surface after the BFAs are loaded, and the fuel-loading guide portion of the loading guide is removed leaving the shield plug guide portion inserted into the canister opening.

- A shield plug port cover installation and removal tool is provided to aid the operator in removal and replacement of the port cover plate. 
- A port cover leak detection fixture is used for helium MSLD testing of the shield plug port cover plate.

- An SSFC closure seal test fixture (domed metal hood) is required for leak checking the SSFC shield plug seal after processing operations are complete and the shield plug port cover plate has been leak checked.

- Manual, torque, and impact wrenches and sockets are supplied to tighten the locking and lifting ring bolts that maintain pressure on the shield plug seal ring and to remove and install the shield plug process port cover plate and the process port connector. These tools are also used to open and close the SSFC shield plug port plug valve with the port connector installed.

- Calibration tools are supplied to verify and recalibrate instrumentation.

All specialty equipment tools are assumed to be classified general service.

\subsection{PROCESS OPERATIONS}

\subsection{CANISTER LOADING INTO CASK}

Specific steps that are required to complete all operations related to the SSFC system are shown in Figure 7 and Figure 8. Canisters with inserts and locking and lifting rings in place will be transported from receiving inspection to the CSB, where they will be stored until needed for $\mathrm{BFA}$ transport. When a cask is available at the CSB, a canister will be removed from storage and placed into the empty cask in the CSB receiving pit. After loading of the canister is complete, the cask lid will be replaced, the lid bolts will be tightened, and the cask lifting yoke will be installed. The cask will then be lifted from the loading pit, placed on the transport trailer, and secured. On completion of all loading operations, the tractor will be backed into the CSB vestibule and attached to the trailer. A survey of the cask will be conducted at the CBS and the cask will be decontaminated, as required, before it is transported to T-Plant. The cask transport trailer is subsequently moved to T-Plant for loading of the BFAs into the canister. A survey report will be provided as part of the cask transport records.

\subsection{T-PLANT RECEIVING}

Prior to cask-SSFC receipt via tractor-trailer, T-Plant operations ensure required systems and equipment are operational and facility technical safety requirements are met. Also, the caskSSFC shipping records are verified for quality assurance acceptability. Upon receipt, while the transporter is still outside the T-Plant railroad tunnel, a shield plug and gasket are removed from 277T storage, assembled with lifting yoke, cleaned, packaged, and placed on the front section of the trailer. An extra assembled shield plug (the shield plug designated for the last SSFC to be loaded) is available for use on the operating deck of the T-Plant canyon, if the shield plug used for SSFC closure somehow becomes damaged or is otherwise unusable. The trailer is then positioned in the T-Plant railroad tunnel to allow access to the cask and supporting equipment. Location of the cask in the T-Plant railroad tunnel must be precise, such that the T-Plant crane has 
access to the top of the SSFC and has ample maneuvering room to conduct operations associated with removal and storage of the cask lid, loading of BFAs, handling of the locking and lifting ring, and installation of the shield plug. Trailer placement must also take into account accessibility of equipment mounted on the railroad tunnel platform located over the end of the trailer that is required for SSFC evacuation, helium backfilling, and leak checking. After trailer positioning, the cask-SSFC trailer is disconnected, the tractor is driven out, the tunnel door is closed, and the trailer is leveled. Radiation surveys are performed and exposure rates are posted. Security and personnel access control systems are established.

\subsection{SHIPPINGPORT SPENT FUEL CANISTER PREPARATION}

As a first step following SSFC receipt, contamination control material is used to cover surfaces on the trailer, including the trailer platform, that could potentially become contaminated. Once this operation is accomplished, the cask lid bolts are unscrewed using impact wrenches or the cask lid torque fixture attached to the T-Plant hoist. When the bolts are loose, the cask lidlifting yoke is picked up by the canyon crane from the laydown area and is attached to the cask lid trunnions. The cask lid is then removed and placed in the lid holder on the trailer.

The cask lid removal operation allows access to the locking and lifting ring, which must be backed out of the threaded portion of the canister collar. To accomplish this task, the locking and lifting ring closure tool is attached to the hoist, removed from the storage cart, and moved into position for tightening the rotating clamp arms that grasp the locking and lifting ring. After the clamps are tightened, the closure tool is manually rotated to remove the locking and lifting ring, which is subsequently moved by the crane to the cart, with the tool attached for storage and later use. With the top of the canister completely open, the canister sealing surface is inspected and cleaned as required. The dual-purpose fuel-loading and shield plug guide tool is then retrieved from storage by the crane and installed on the canister opening. Extreme care must be exercised to assure that there is no damage to the shield plug gasket surface and the threads for the locking and lifting ring on the canister collar. Also note that the fuel-loading guide is designed to extend over the top surfaces of the canister and cask to protect the cask from contamination that might drip from the BFAs. At this point, the canister is ready for loading of the BFAs.

\subsection{BLANKET FUEL ASSEMBLY LOADING}

In order to conduct BFA loading operations, all personnel must be evacuated from the canyon and tunnel areas. The T-Plant crane is then connected to the desired BFA, per the canister loading plan, and the BFA is removed from the pool. The BFA will be held above the pool area for about 1 hour to allow the water to drain and evaporate from the assembly and to allow free water captured in the cavity of the top extension bracket to be removed by siphoning, pumping, or aeration, if necessary. At this time, the BFA is visually inspected and the assembly markings are verified using the closed-circuit television camera mounted on the canyon deck. When water dripping is no longer evident and/or a specific hold time has passed, the BFA is positioned over 
the SSFC and lowered into the canister. This process is repeated four times to complete the loading of the required number of BFAs into the canister.

A BFA loading plan will be developed for each SSFC that minimizes dose rates for operating personnel. A nominally loaded SSFC will contain only one high-burnup assembly with three lower burnup assemblies. The assemblies with the lowest burnup will be located in the canister so that dose rates will be ALARA where the operator(s) will be working on the trailer work platform. For those SSFCs containing a high burnup assembly, efforts will be made to locate these assemblies as far as possible from the operators.

After BFA loading is accomplished, the fuel-loading guide portion of the loading tool is carefully removed from the SSFC using the hoist and stored in the T-Plant canyon as a contaminated fixture. The shield plug guide portion remains installed. Following this operation, the shield plug with the handling fixture attached and assembled with seal is picked up by the hoist. As the shield plug is lifted and then lowered into the canister opening, the crane operator must exercise caution to assure there is no damage to the canister locking and lifting ring threads and shield plug gasket sealing surface. After the seal plug is properly inserted, the shield plug guide portion of the loading tool is removed.

When the operations for shield plug insertion in the canister opening are completed, radiological surveys will be performed and personnel are allowed access to the trailer platform for the shield plug sealing operations. The lifting fixture is disconnected from the shield plug and moved to storage, and the locking and lift ring closure tool with the locking and lifting ring secured is picked up by the hoist. As the next step, the locking and lifting ring is inserted into the canister opening over the shield plug and manually threaded inward to hold the shield plug in place. The hydraulic ram on the closure tool is then activated to apply downward pressure on the shield plug and compress the shield plug seal. When the shield plug is correctly positioned, each of the 18 bolts on the locking and lifting ring is tightened (manually or by use of an air-powered wrench) to a specified torque that retains the required pressure to the shield plug and metallic seal. When the locking and lifting ring is correctly positioned, the closure tool is disconnected from the locking and lifting ring and stored.

\subsection{SHIPPINGPORT SPENT FUEL CANISTER PROCESSING}

Various process operations that are performed on the SSFC after BFA loading are shown on the flow diagram in Figure 8. Completion of the canister sealing operations is followed by SSFC vacuum and helium backfilling operations. The drying and inerting system module is prepositioned on the railroad tunnel work platform extending over the top back end of the trailer. Also, two helium bottles attached to a supply manifold are placed in a location near the railroad tunnel work platform, and a connection is made to the drying and inerting system manifold.

As an initial step, the shield plug port cover is removed. A 4-bolt port connector with O-ring seals is then attached to the shield plug flange opening, and a hose connection is made between the vacuum manifold system and the port connector. The drying and inerting system is turned on, and a pressure rebound test is performed to verify the port connector is sealed. The 
shield plug port valve is then opened to allow evacuation of the sealed SSFC. Gauges are monitored to verify pump down of the SSFC to $<3.0$ torr. The time period allowed for pump down to a specific pressure will depend on the amount of water present and will be determined by conducting tests on a mockup SSFC. When the initial pump down is finished, the SSFC will be backfilled with helium, and evacuated and backfilled a second time. An SSFC pressure rebound test will be implemented on the second pump down to assure moisture has been removed from the BFAs. Current plans are to evacuate and backfill only two times, but additional cycles could be necessary depending on the outcome of the testing activities. The SSFC will be pressurized with helium to $\sim 2$ psi after completion of the pressure rebound test, and the port plug valve will be closed. If SSFC gas sampling is required after isolation from the helium supply, the port plug valve will be opened and a sample of the gas within the SSFC will be taken and analyzed. If gas analysis results are acceptable, the port plug valve will be closed, applying proper torque to seal the metallic gasket under the valve plug. On completion of SSFC processing operations, the shield plug port connector is removed and the surface of the shield plug is checked for contamination. A cover is placed over the open end of the port connector to assure there is no contamination leakage from the vacuum line prior to the filters.

\subsection{CLOSURE AND LEAK CHECKING}

Final SSFC closure steps at the T-Plant involve using the MSLD skid pre-positioned on the railroad tunnel work platform, installing the port plug valve cover, and leak checking the port cover and SSFC shield plug seals. The port cover is inserted and bolted in place, and a helium MSLD test is then conducted on the port cover using a special fixture. Calibration of the MSLD prior to testing is mandatory. On verification of the port cover leak tightness, the hoist is used to place the SSFC closure seal test fixture over the top of the SSFC. Leak tightness of the shield plug gasket seal is verified by making connections to the closure seal test fixture and pulling a vacuum over the top of the SSFC using the helium MSLD. When leak checking is completed, the closure seal text fixture is removed and stored for further use.

\subsection{SHIPPING}

Once SSFC leak tightness is verified, the cask is ready to be sealed and prepared for shipment. The cask lid O-ring gasket is replaced as required, the cask lid is picked up by the T-Plant crane using the lid lifting fixture yoke, and the lid is lowered into place. The cask lid torque fixture is used to torque the bolts to specification. When cask closure is verified, the protective contamination control material is removed from the trailer, and radiation and contamination surveys are performed.

The trailer is then prepared for transport. The railroad tunnel door is opened and the tractor is brought into the T-Plant railroad tunnel and connected. The standard pre-trip inspections are conducted, and the cask, along with the SSFC quality assurance package, is released for transfer to the CSB. 


\subsection{CAP WELDING AND STORAGE}

After SSFC processing operations are complete, the cask-SSFC will be transported to the CSB. At the CSB, pre-operation setup and inspections are conducted to receive an SSFC loaded with BFAs, through coordination with T-Plant operations. The transporter is backed into the CSB vestibule, stabilized, and disconnected from the tractor. The lifting yoke is attached to the cask trunnions, and the cask containing the SSFC is then removed from the trailer and placed into the receiving pit. Removal of the cask lid is achieved by using the torque tool to loosen the lid bolts, attaching the lid yoke, and using the receiving crane to move the cask lid to the inspection table. After suitable preparations, the MHM is used to remove the SSFC from the cask and transport the SSFC to interim staging in a storage tube or to the weld station.

At the weld station, the weld cap is placed on the SSFC and the weld equipment is positioned for final closure. A two-stage weld involving separate passes is used to provide the closure seal for the SSFC. The cap weld is cleaned and inspected, and the SSFC is released for long-term storage. The SSFC is moved to a designated storage tube using the MHM, lowered into a tube, and the tube is covered with a plug. The above operations constitute the final steps required to place the BFAs into long-term storage at the CSB.

\subsection{MAINTENANCE/CALIBRATION}

Drying and inerting system and leak checking components are designed to be functionally tested, given a specific process condition input. System operability is verified by surveillance of the system's operability status and component states (e.g., valve positions and pressure readings) as the system is operated for each SSFC process cycle. Periodic calibration and testing of drying and inerting system components are dictated by the requirements of the individual components, according to the respective manufacturer's recommended schedules and practice, and are administered by controlled procedures for all safety-significant SSCs.

Recalibration of signals from the pressure transmitters used for the drying and inerting system and helium backfilling is maintained according to the respective manufacturer's recommended schedule and practice. The drying and inerting system is designed with calibration and test connections to enable periodic in-service measurement and calibration of all setpoints and adjustments that affect the manner in which the drying and inerting system performs.

The helium leak test system must be periodically calibrated with a National Institute of Standards and Technology traceable calibration standard in the $10^{-7}$ standard $-\mathrm{cm}^{3} / \mathrm{sec}$ range. The helium standard must be continuously evacuated by an auxiliary pump just prior to being released into the system. Helium response time and system sensitivity shall be included in the test report.

There are no specific equipment maintenance requirements identified at this time. Since ample time is available for processing a single SSFC, equipment can be easily refurbished during normal process operations. Spare drying and inerting system components and a spare MSLD will be available that can be used to repair or replace a defective system, if necessary, without major impacts to the SSFC loading schedule. 
SNF-5809, REV 0

\subsection{REFERENCES}

10 CFR 72, 1995, "Licensing Requirements for the Independent Storage of Spent Nuclear Fuel and High-Level Radioactive Waste," Code of Federal Regulations.

ANSI N14.5, 1997, American National Standard for Radioactive Materials - Leakage Tests on Packages for Shipment, American National Standards Institute, New York, New York.

ANSI/ANS 8.12, 1993, Nuclear Criticality Control and Safety of Homogeneous PlutoniumUranium Fuel Mixtures Outside Reactors, American Nuclear Society, La Grange Park, Illinois.

ASME, 1995, American Society of Mechanical Engineers (ASME) Boiler and Pressure Vessel Code, American Society of Mechanical Engineers, New York, New York.

ASME, 1998, American Society of Mechanical Engineers (ASME) Boiler and Pressure Vessel Code, Section III, "Rules for Construction of Nuclear Power Plant Components," Division 1, Subsection NB, "Class 1 Components," American Society of Mechanical Engineers, New York, New York.

ASTM A500-96, 1996, Standard Specification for Cold-Formed Welded and Seamless Carbon Steel Structural Tubing in Rounds and Shapes, American Society for Testing and Materials, West Conshohocken, Pennsylvania.

Benz, E. F., 1977, (internal memorandum WAPD-MT(CRCT)-45 to F. L. Lau, August), Crud Activity Estimates for PWR Core 2 Core Cage \& Thermal Shield, Bettis Atomic Power Laboratory, West Mifflin, Pennsylvania.

DOE-STD-3009-94, 1994, Preparation Guide for U.S. Department of Energy Nonreactor Nuclear Facility Safety Analysis Reports, U.S. Department of Energy, Washington, D. C.

HNF-3043, 2000, Performance Specification, Fuel Drying and Canister Inerting System for Shippingport Pressurized Water Reactor (PWR) Core-2 Blanket Fuel Assemblies Stored Within Shippingport Spent Fuel Canisters, Rev. 1, Fluor Hanford, Incorporated, Richland, Washington.

HNF-3553, Annex A, Canister Storage Building Final Safety Analysis Report, Addendum A, 2000, "Shippingport PWR Core 2 Fuel Storage at Canister Storage Building," Rev. 0, Draft, Fluor Federal Services, Richland, Washington.

HNF-4109, 1999, Thermal Assessment of Shippingport Pressurized Water Reactor Blanket Fuel Assemblies Within a Multi-Canister Overpack Within the Canister Storage Building, Rev. 0, Numatec Hanford Corporation, Richland, Washington.

HNF-PRO-704, Hazard and Accident Analysis Process of DOE-STD-3009-94, Preparation Guide for U. S. Department of Energy Nonreactor Nuclear Facility Safety Analysis Reports, U. S. Department of Energy, Washington D. C. 
HNF-SD-SNF-CSER-005, 2000, Criticality Safety Evaluation Report for the Multi-Canister Overpack, Rev. 5B, Fluor Hanford, Incorporated, Richland, Washington.

HNF-SD-SNF-TI-061, 1999, Shippingport Pressurized Water Reactor Core 2 Blanket Assemblies Source Term Calculations Using ORIGEN2, Rev. 1, Fluor Daniel Northwest, Incorporated, Richland, Washington. (Wittekind, W. D, 1999)

HNF-SD-TP-SARP-017, 2000, Safety Analysis Report for Packaging (Onsite) Multicanister Overpack Cask, Rev. 3 (to be published), Fluor Hanford, Incorporated, Richland, Washington.

HNF-SD-WM-ISB-006, 1999, Interim Safety Basis for Solid Waste Facilities (T-Plant), Rev. 1A, Waste Management Federal Services of Hanford, Incorporated, Richland, Washington.

Howard, G. T., 1977, Arrangements for PWR-2 Spent Fuel Shipments Using the N-160 Shipping Container, (letter WAPD-LP[CES]CS-105 to D. J. Cockeram, Rockwell Hanford Operations, Richland, Washington, November), Bettis Atomic Power Laboratory, West Mifflin, Pennsylvania.

NRC Regulatory Guide 7.11, 1991, Fracture Toughness Criteria of Base Material for Ferritic Steel Shipping Cask Containment Vessels with a Maximum Wall Thickness of $4 \mathrm{in}$. $(0.1 \mathrm{~m})$, U.S. Nuclear Regulatory Commission, Washington, D.C.

NUREG-1536, 1996, Standard Review Plan for Dry Cask Storage Systems, U.S. Nuclear Regulatory Commission, Washington, D.C.

NUREG/CR-3019, 1985, Recommended Welding Criteria for Use in the Fabrication of Shipping Containers for Radioactive Materials, U.S. Nuclear Regulatory Commission, Washington, D.C.

NUREG/CR-3854, 1984, Fabrication Criteria for Shipping Containers, UCRL-53544 U.S. Nuclear Regulatory Commission, Washington, D.C.

PNL-6365, 1987, Evaluation of Cover Gas Impurities and Their Effects on the Dry Storage of LWR Spent Fuel, Pacific Northwest Laboratory, Richland, Washington. (Knoll, R. W., and Gilbert, E. R., 1987)

SNF-5133, 2000, Shippingport, Spent Fuel Canister Design Report, Draft, Fluor Hanford, Incorporated, Richland, Washington.

SNF-5191, 2000, Shippingport Spent Fuel Canister and Shield Plug Fabrication Specification, Draft, Fluor Hanford, Incorporated, Richland, Washington.

SNF-5192, 2000, Shippingport Spent Fuel Canister Insert Fabrication, Draft, Fluor Hanford, Incorporated, Richland, Washington.

WAPD-296, 1968, PWR Core 2 Reactor Design Description Report, Bettis Atomic Power Laboratory, Pittsburgh, Pennsylvania.

WAPD-335, 1983, Shippingport Operations During PWR Core 2 Depletion (April 1965 to February 1974), Bettis Atomic Power Laboratory, West Mifflin, Pennsylvania. 
WHC-SD-WM-ES-394, 1996, Removal Plan for Shippingport Pressurized Water Reactor Core 2 Blanket Fuel Assemblies for T Plant to the Canister Storage Building, Rev. 0 , Westinghouse Hanford Company, Richland, Washington. 
SNF-5809, REV 0

This page intentionally left blank. 
Figure 1. Shippingport Spent Fuel Canister Assembly.
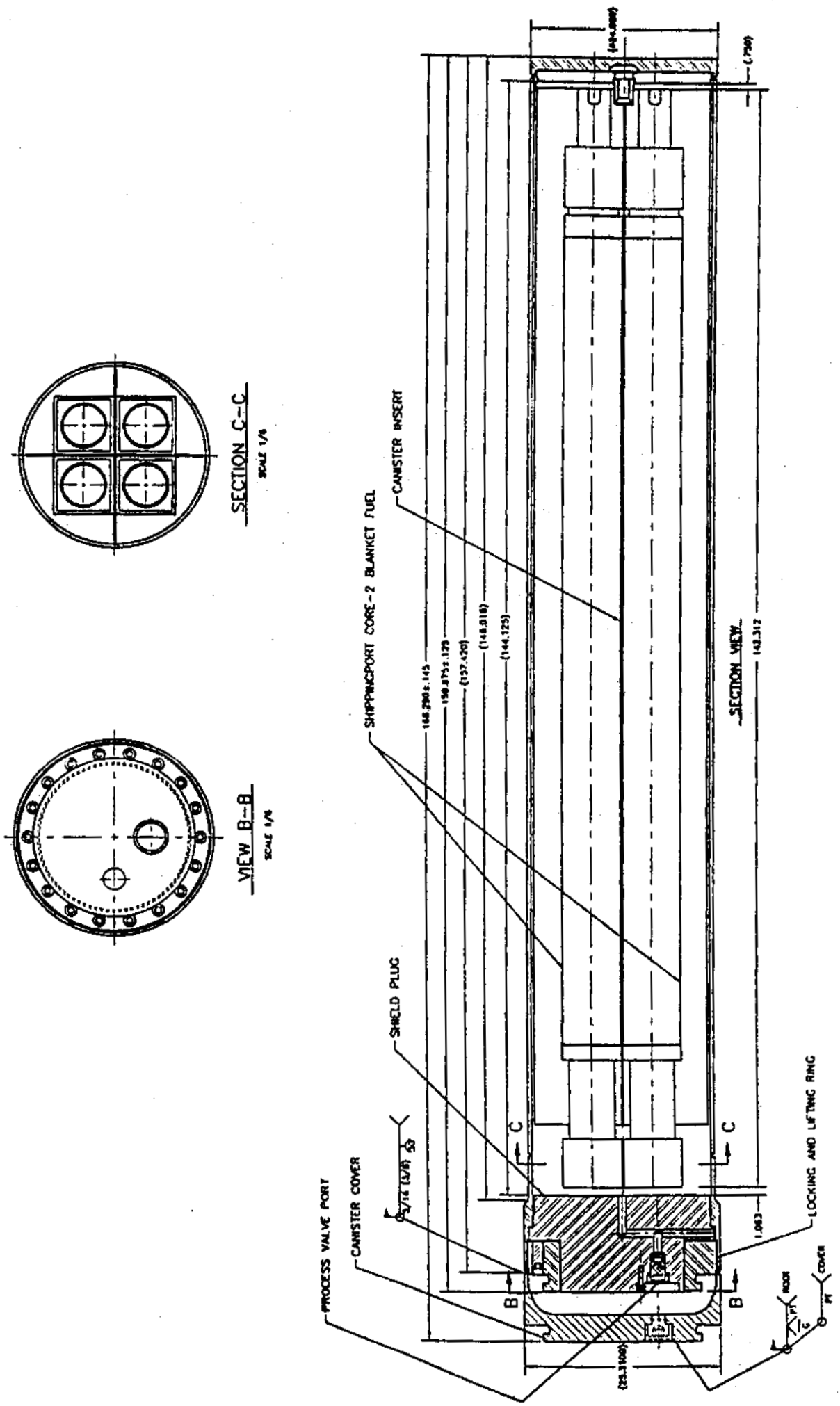
SNF-5809, REV 0

Figure 2. Shippingport Pressurized Water Reactor Core 2 Blanket Fuel Assembly.

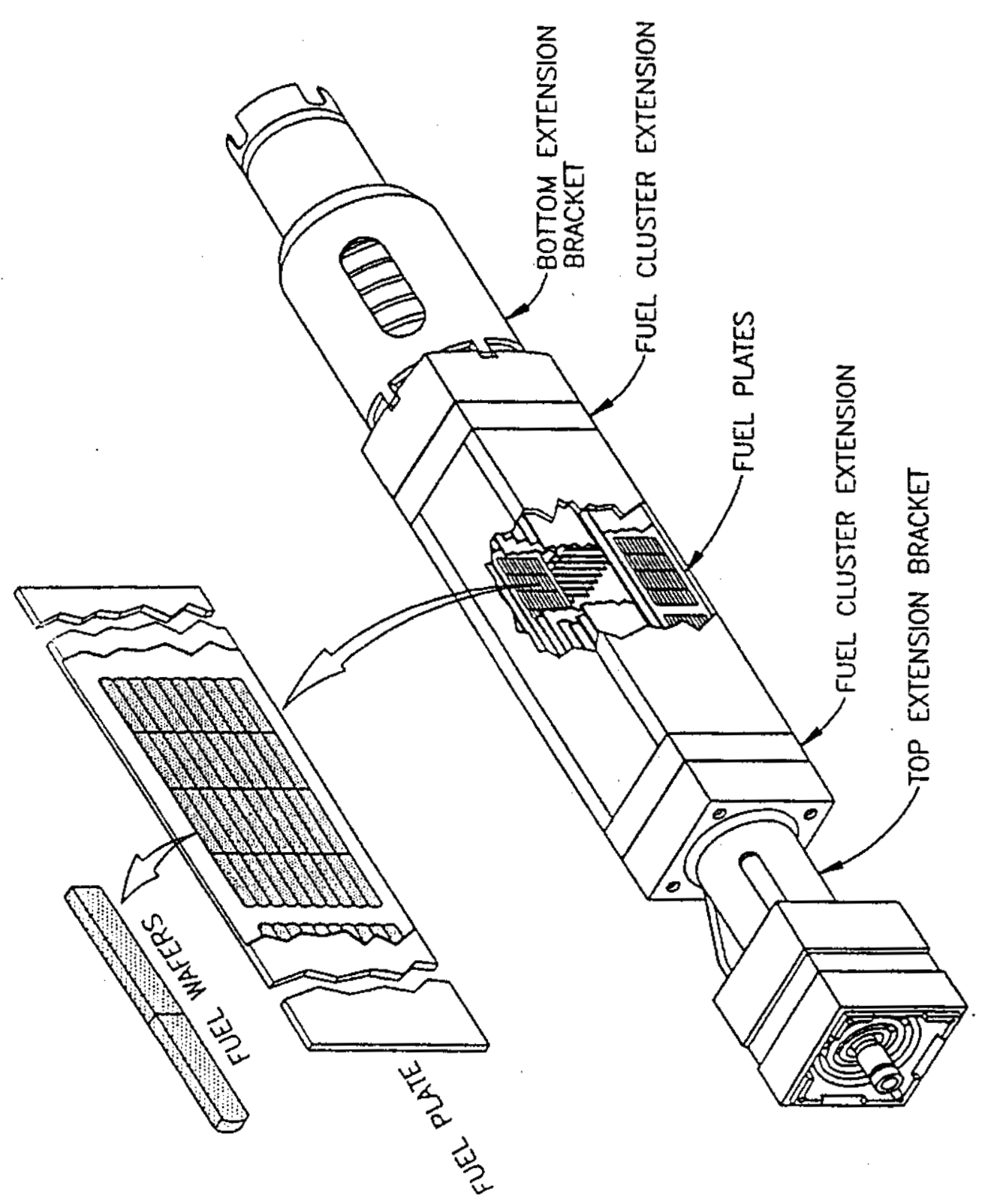


Figure 3. Shield Plug with Cross-Section Showing Port Plug Valve, Cover Plate, and Canister Seal.
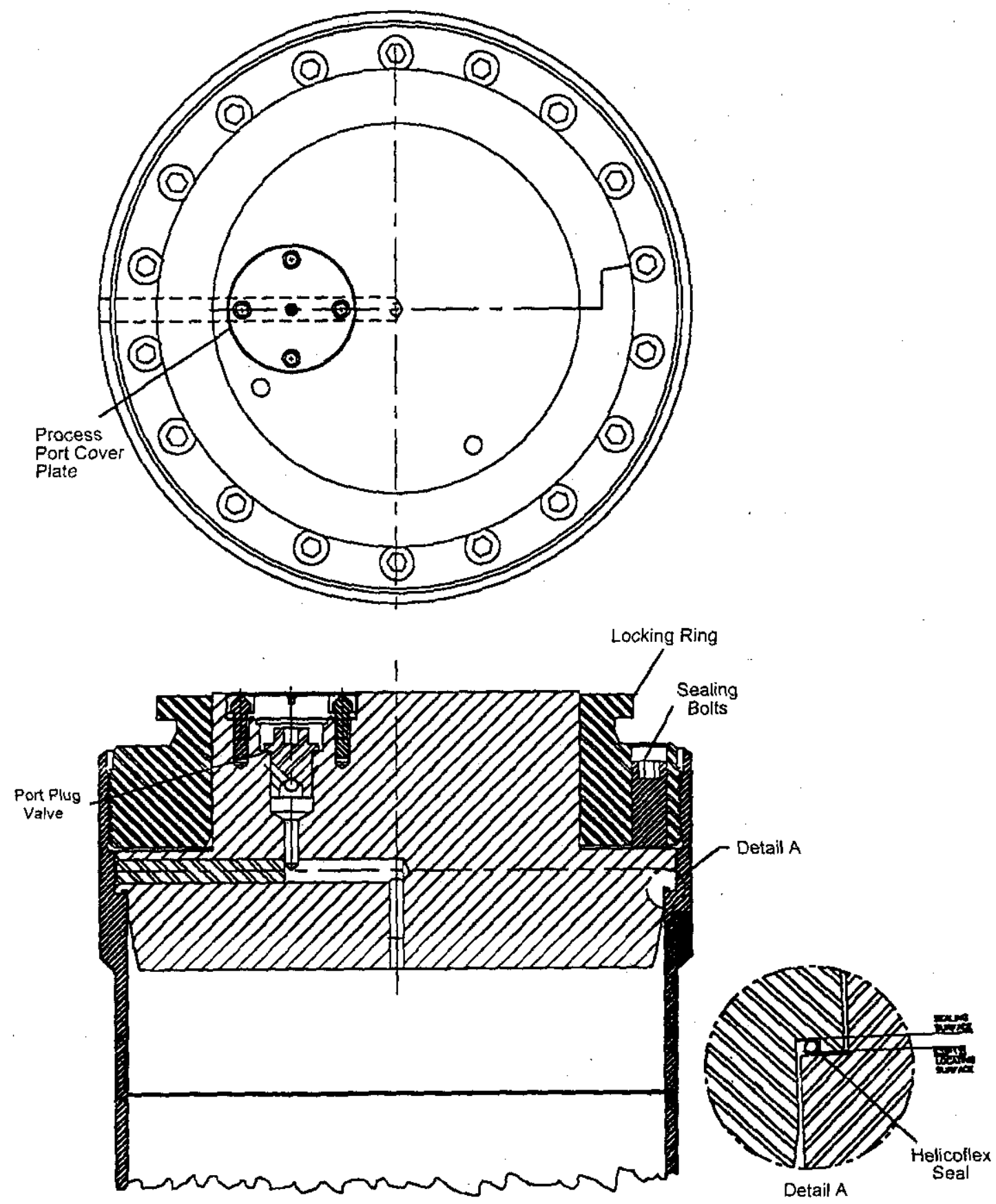
SNF-5809, REV 0

Figure 4. Shippingport Pressurized Water Reactor Core 2 Blanket Fuel Assembly Details.

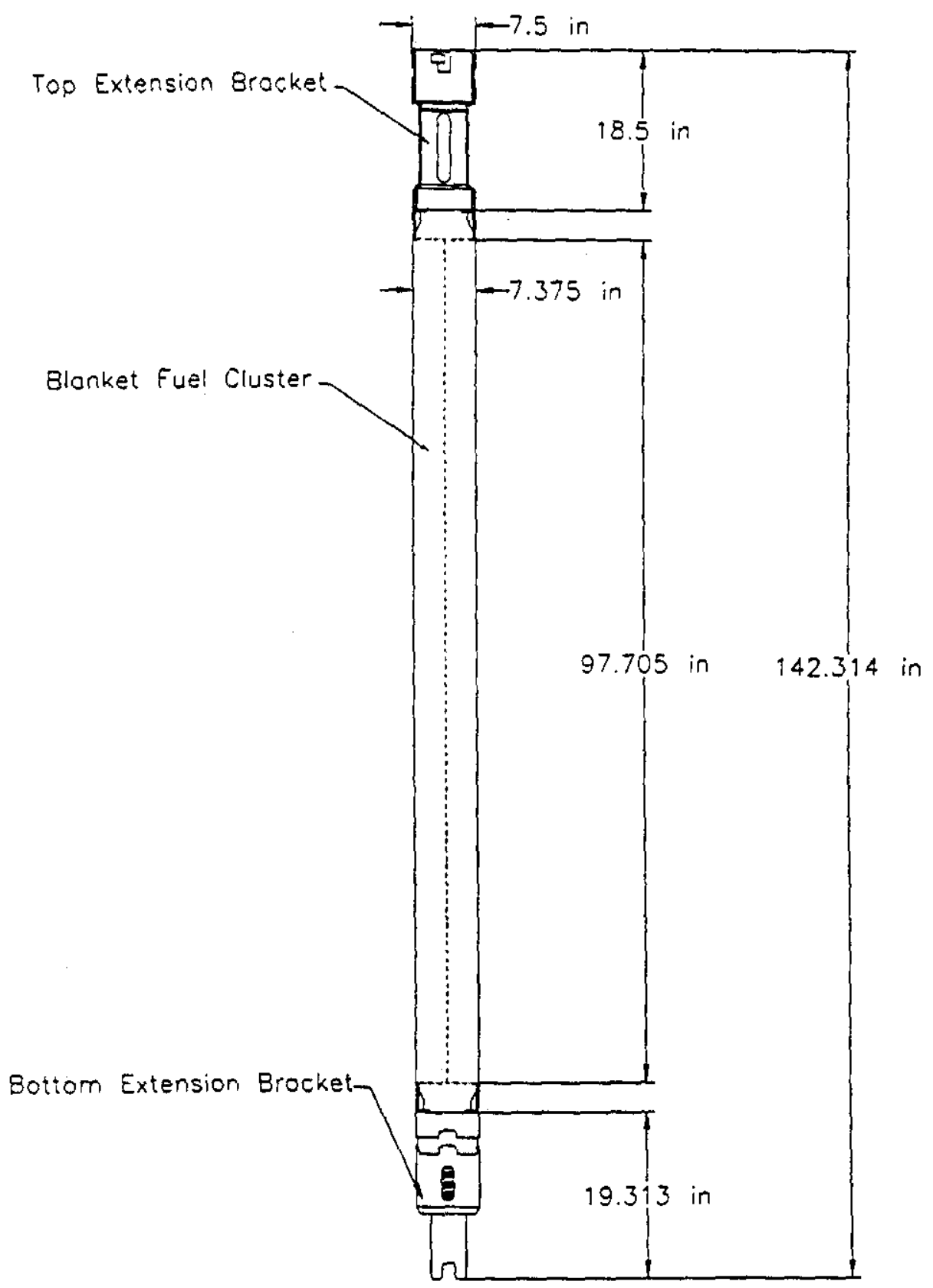


Figure 5. Shippingport Pressurized Water Reactor Core 2 Blanket Fuel Cluster Details.
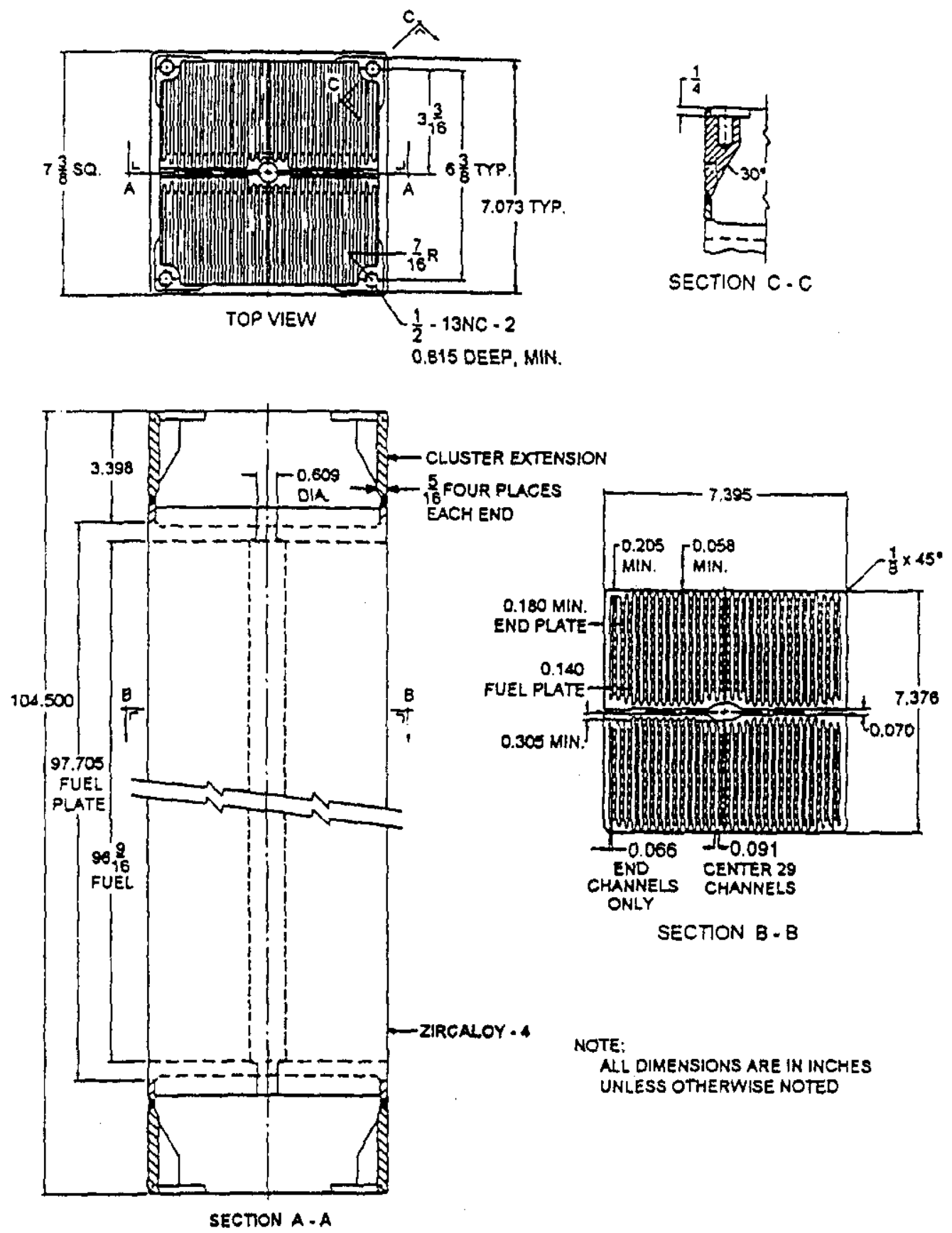
Figure 6. Schematic Diagram of Drying and Inerting System Module.

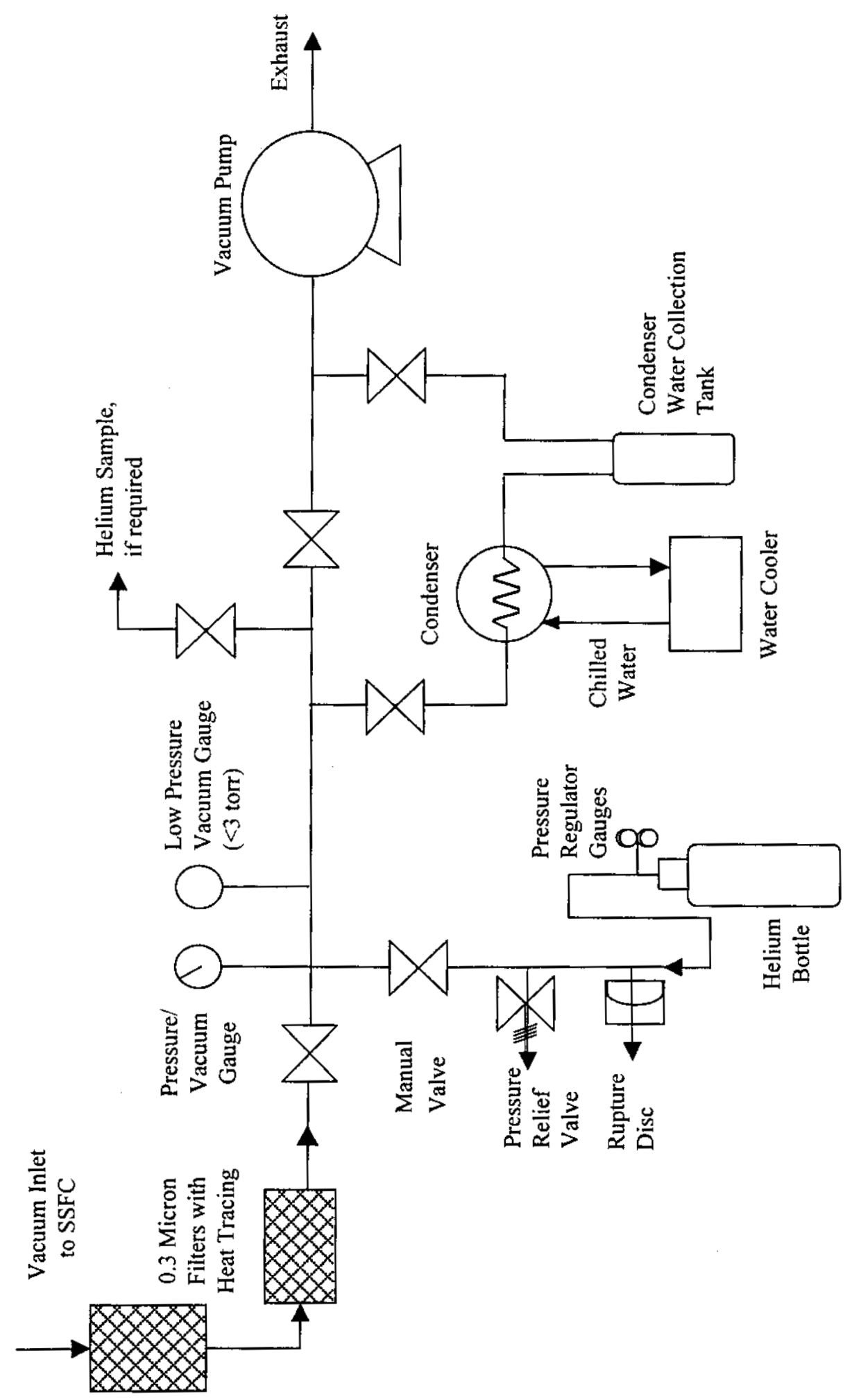




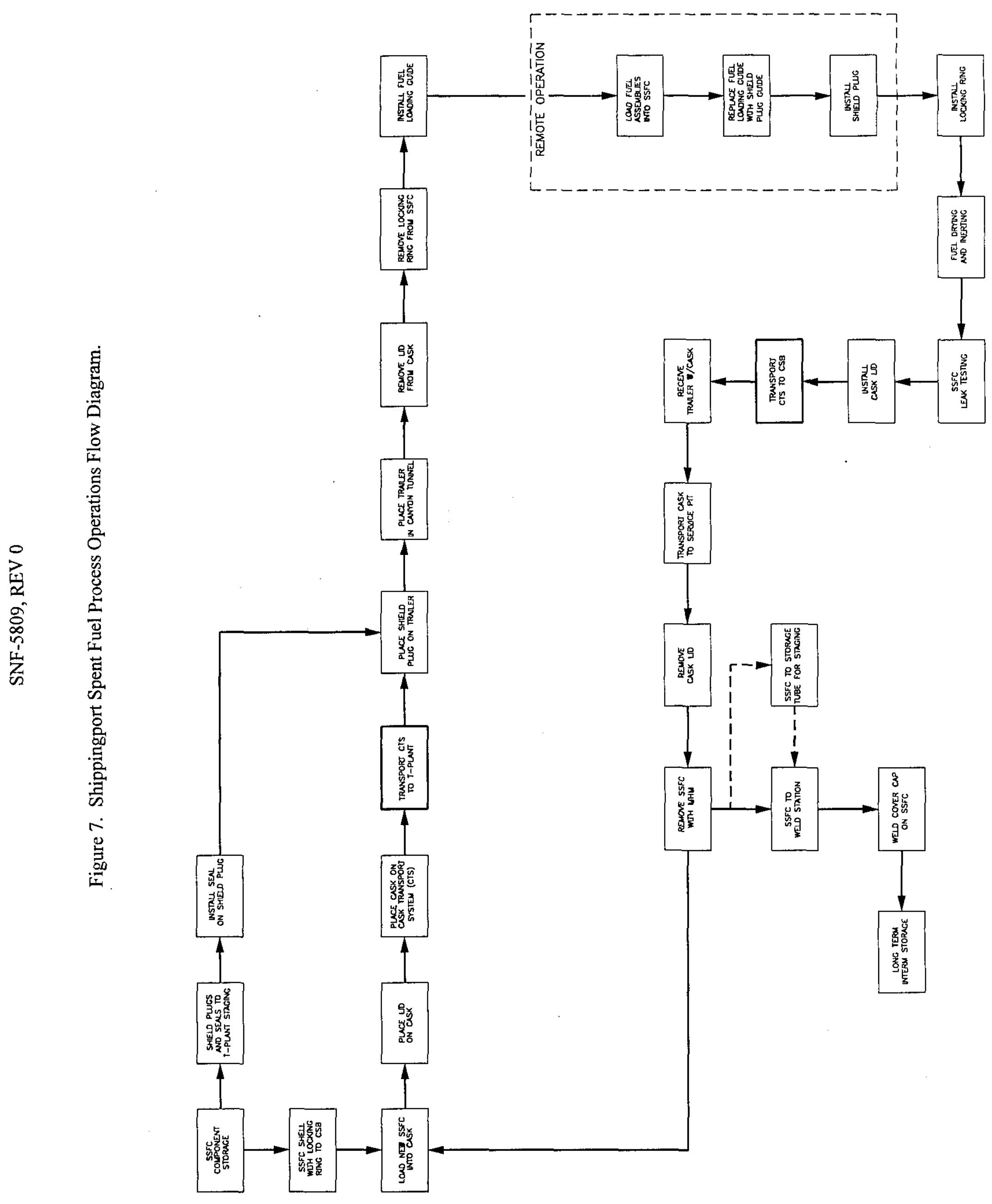




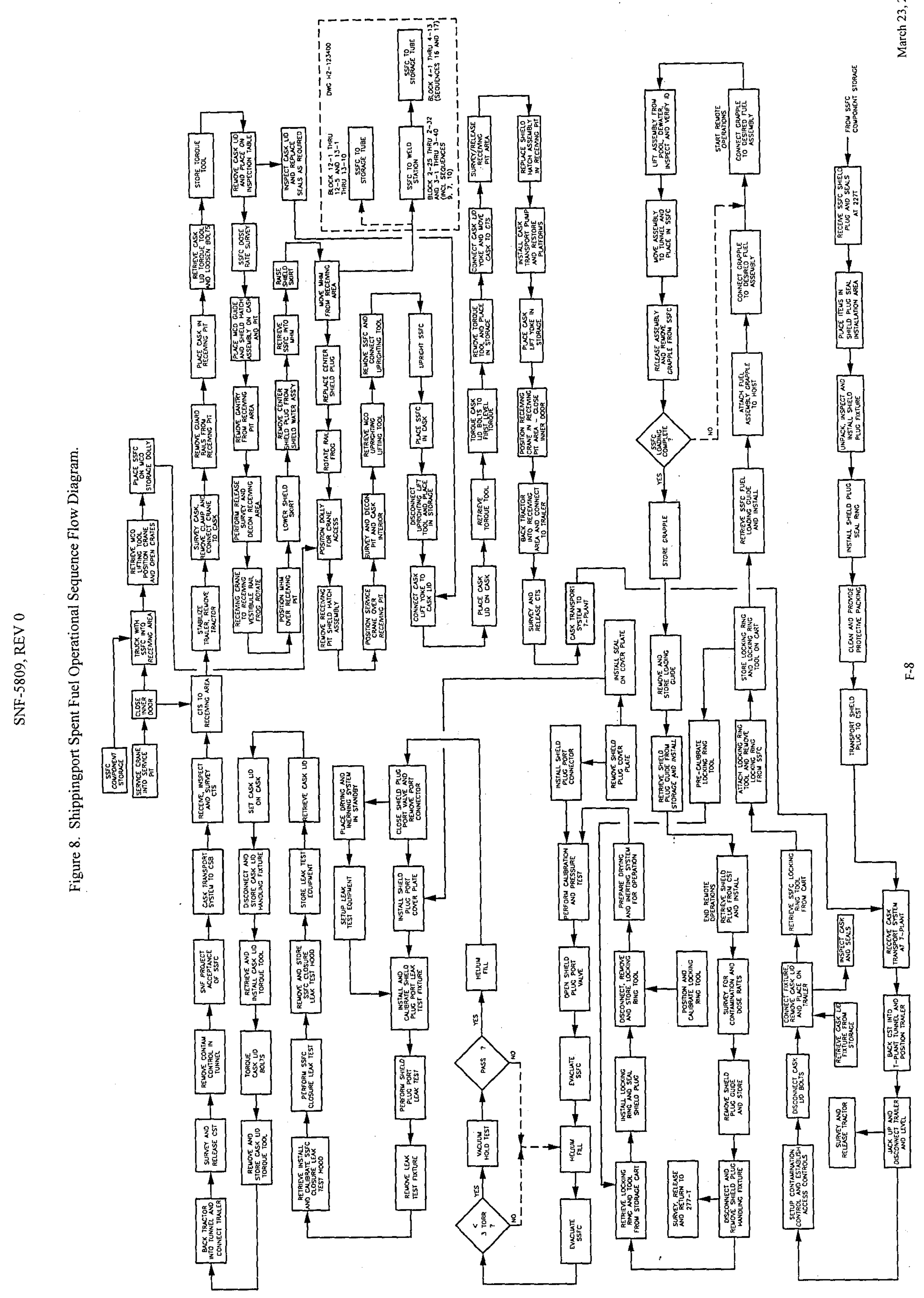




\section{DISTRIBUTION SHEET}

To

Distribution

Project Title/Work Order

Shippingport spent Fuel Canister

Name

W.S. Ayers

R.D. Carrell

D.M. Johnson

(6)

O.L. Kruger

R.L. McCormack

O.L. Serrano

J.S. Turnbaugh

D.J. Watson
From

D.M. Johnson \begin{tabular}{l} 
Page of \\
Date 3/24/00 \\
\hline EDT No. 628669 \\
\hline ECN No.
\end{tabular}

\begin{tabular}{c|c|c|c|}
\hline $\begin{array}{c}\text { Text } \\
\text { With All } \\
\text { Attach. }\end{array}$ & Text Only & $\begin{array}{c}\text { Attach./ } \\
\text { Appendix } \\
\text { Only }\end{array}$ & $\begin{array}{c}\text { EDT/ECN } \\
\text { Only }\end{array}$ \\
\hline
\end{tabular}

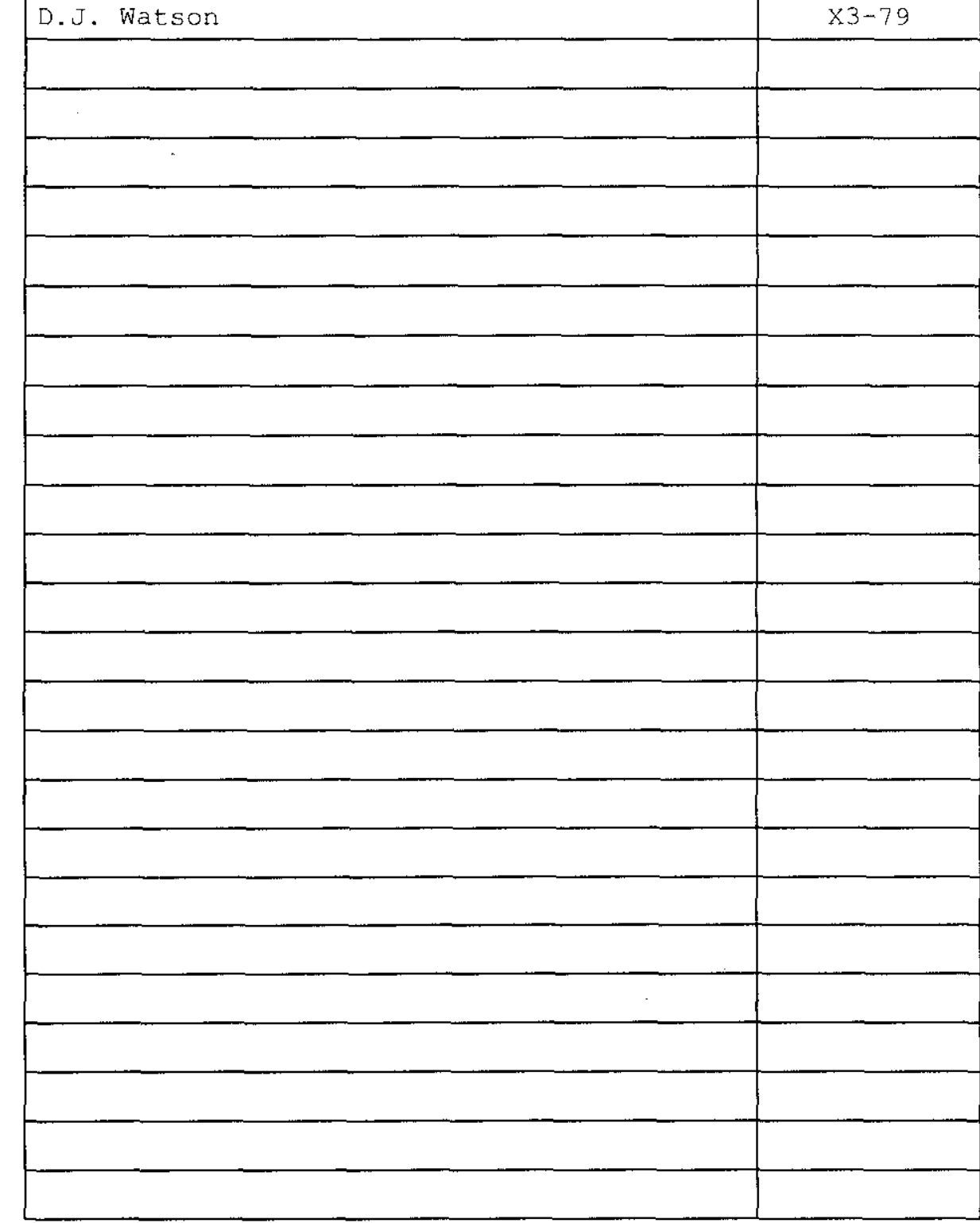

\begin{tabular}{|c|}
\hline MSIN \\
\hline T3-28 \\
\hline R3-11 \\
\hline R3-11 \\
\hline R3-13 $3-11$ \\
\hline $\mathrm{S} 2-44$ \\
\hline $\mathrm{X} 3-79$ \\
\hline \\
\hline
\end{tabular}

